\title{
The White Primary Rulings: A Case Study in the Consequences of Supreme Court Decisionmaking
}

\section{Citation}

Michael J. Klarman, The White Primary Rulings: A Case Study in the Consequences of Supreme Court Decisionmaking, 29 Fla. St. U. L. Rev. 55 (2001).

\section{Published Version}

http://diginole.lib.fsu.edu/fsulr/vol29/iss1/2/

\section{Permanent link}

http://nrs.harvard.edu/urn-3:HUL.InstRepos:12989027

\section{Terms of Use}

This article was downloaded from Harvard University's DASH repository, and is made available under the terms and conditions applicable to Other Posted Material, as set forth at http:// nrs.harvard.edu/urn-3:HUL.InstRepos:dash.current.terms-of-use\#LAA

\section{Share Your Story}

The Harvard community has made this article openly available.

Please share how this access benefits you. Submit a story.

Accessibility 


\section{FLORIDA STATE UNIVERSITY}

LAW REVIEW

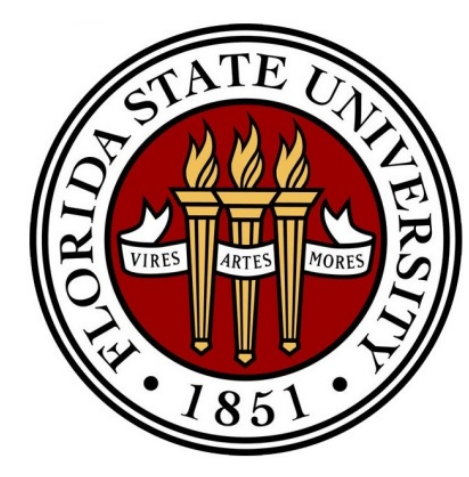

The White Primary Rulings: A CASE Study in the CONSEquences of SuPREME COURT DECISIONMAKING

Michael J. Klarman

NUMBER 1

VOLUME 29

FALL 2001

Recommended citation: Michael J. Klarman, The White Primary Rulings: A Case Study in the Consequences of Supreme Court Decisionmaking, 29 FLA. ST. U. L. REV. 55 (2001). 


\title{
THE WHITE PRIMARY RULINGS: A CASE STUDY IN THE CONSEQUENCES OF SUPREME COURT DECISIONMAKING
}

\author{
MiCHAEL J. KLARMAN*
}

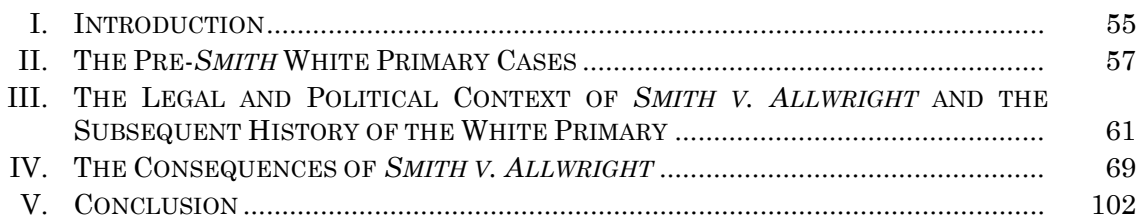

\section{INTRODUCTION}

Political scientists and legal scholars have written a good deal in recent years on the consequences of Supreme Court decisions. ${ }^{1}$ Much of this scholarship has been skeptical of the Court's capacity to produce significant social change. Most notably, Professor Gerald N. Rosenberg has declared the notion that courts can reform society a "hollow hope." ${ }^{2}$ Rosenberg shows that Brown v. Board of Education ${ }^{3}$ produced very little school desegregation until Congress passed landmark civil rights legislation to implement the Court's ruling. ${ }^{4} \mathrm{He}$ also makes a strong case that Brown played a less instrumental role in the 1960 s civil rights movement than is commonly believed. ${ }^{5}$ Simi-

\footnotetext{
*James Monroe Professor of Law, Albert C. Tate, Jr., Research Professor, and Professor of History, University of Virginia. B.A., M.A., University of Pennsylvania; J.D., Stanford Law School; D. Phil., Oxford University. I am grateful to Daryl Levinson, Rick Pildes, and Mark Tushnet for their helpful comments on an earlier draft. Stephanie Russek provided extraordinary research assistance, and, as always, I am indebted to the reference librarians at the University of Virginia School of Law for the superb research help they regularly provide. A revised version of this Article will appear in a chapter of my forthcoming book, provisionally entitled NeIther Hero, Nor Villain: The Supreme Court, RACE AND THE Constitution in the Twentieth Century (Oxford Univ. Press). As the Mason Ladd lecturer at The Florida State University College of Law in February, 2001, I was privileged to present material from a different chapter of that book. I am grateful to both the students and the faculty at Florida State for the warm and enthusiastic reception they accorded me on that occasion. I owe special thanks to Mark Seidenfeld for making that occasion possible.

1. See, e.g., Gerald N. Rosenberg, The Hollow Hope: Can Courts Bring About Social Change? (1991); LeVeraging the LaW: Using the Courts to Achieve Social Change (David A. Schultz ed., 1998); Stephen L. Wasby, The Impact of the United States Supreme CourT: SOME PERSPECTIVES (1970).

2. ROSENBERG, supra note 1.

3. 347 U.S. 483 (1954).

4. RosenBerG, supra note 1 , at 49-54.

5. Id. at 107-56. See also Gerald N. Rosenberg, Brown Is Dead! Long Live Brown!: The Endless Attempt to Canonize a Case, 80 VA. L. REV. 161 (1994) (giving Brown almost no credit for inspiring the civil rights movement). But cf. David J. Garrow, Hopelessly Hollow History: Revisionist Devaluing of Brown v. Board of Education, 80 VA. L. REV. 151 (1994) (giving Brown tremendous credit); Michael J. Klarman, Brown, Racial Change, and the Civil Rights Movement, 80 VA. L. REV. 7 (1994) (arguing that Brown indirectly acceler-
} 
larly, my own research has found that the Supreme Court's first major criminal procedure decisions, which disproportionately involved Southern blacks who had suffered egregious mistreatment from the Jim Crow criminal justice system, had almost no impact on reforming that system. ${ }^{6}$ Southern blacks continued to be almost universally excluded from juries, beaten into confessing crimes they may or may not have committed, and convicted of capital offenses after sham trials in which generally apathetic court-appointed lawyers simply went through the motions of providing a defense.

It would be a mistake, however, to conclude on the basis of such studies that Supreme Court decisions in the civil rights context never made a difference. ${ }^{7}$ The Court's most important white primary decision, Smith v. Allwright, ${ }^{8}$ inaugurated a political revolution in the urban South. This Article considers both the circumstances that enabled Smith to accomplish what it did and the limitations of that accomplishment. My goal is to shed light on the conditions that enable and disable Supreme Court decisions from effectuating significant social change. ${ }^{9}$

Part II summarizes the Supreme Court's three pre-Smith white primary decisions. Part III describes Smith's legal and political background and also relates the post-Smith history of the white primary. Part IV, the core of the Article, describes the impact of Smith on Southern black voter registration. Relying principally on archival material mined from the NAACP Papers, I describe how Southern

ated the pace of racial change by crystallizing Southern white resistance, which led to violent confrontation followed by national intervention in the form of civil rights legislation).

6. Michael J. Klarman, The Racial Origins of Modern Criminal Procedure, $99 \mathrm{MicH}$. L. REV. 48, 77-88 (2000) [hereinafter Klarman, Criminal Procedure]; Michael J. Klarman, Is the Supreme Court Sometimes Irrelevant? Race and the Southern Criminal Justice System in the World War II Era, J. AM. HIST. (forthcoming 2002) [hereinafter Klarman, Southern Criminal Justice System].

7. My claim in this Article is that the Court's ruling in Smith v. Allwright, 321 U.S. 649 (1944), had significant, direct, and immediate consequences for Southern black voter registration. I have argued elsewhere that legal scholars and historians should be more attentive to the possibility that the process of litigation, wholly apart from whether it produced victories in court and whether those court victories translated into concrete changes in social practices, should be understood as an important facet of the early civil rights movement. Klarman, Criminal Procedure, supra note 6, at 88-92; Michael J. Klarman, Race and the Court in the Progressive Era, 51 VAND. L. REV. 881, 949-52 (1998) [hereinafter Klarman, Progressive Era]. Litigation educated Southern blacks about their rights, provided occasions for organizing local communities, displayed prominent black lawyers such as Charles Houston and Thurgood Marshall as role models for Southern blacks, and educated Northern whites (and Northern judges) about the egregiousness of Jim Crow conditions in the South.

8. 321 U.S. 649 (1944).

9. I regard this Article as supplementing, rather than refuting or even challenging, the claims made by Gerald Rosenberg in THE HoLLOW HOPE. Rosenberg explicitly acknowledges that courts can produce social change under the right set of political and social conditions. ROSENBERG, supra note 1, at 30-36. One of my objectives here is to explore the conditions under which litigation has proven conducive to social change. 
blacks and whites responded to Smith and identify the political and social conditions that enabled Smith to launch a revolution in black political participation in the urban South. Part IV also examines the factors that largely nullified the impact of Smith in the rural South. A brief conclusion addresses the question of why the Supreme Court's intervention in the white primary context was so much more immediately efficacious than its contemporaneous decisions involving criminal procedure issues affecting Southern blacks or its slightly later ruling in Brown.

\section{The Pre-SMith White PRIMARy CASES}

The Supreme Court considered the constitutionality of the white primary on three separate occasions prior to Smith $v$. Allwright. ${ }^{10}$ In 1927, the Court in Nixon v. Herndon ${ }^{11}$ invalidated a Texas statute barring black participation in party primaries. This was by far the easiest of the three pre-Smith cases for the Court because state action was unquestionably present. For many years prior to Herndon, the Court had interpreted both the Fourteenth and Fifteenth Amendments to forbid race discrimination only by the state and not by private entities. ${ }^{12}$ For a political party to exclude blacks from membership raised complicated questions regarding the scope of the state action requirement: Was a political party a public or a private entity? Were elections a public function for which the state was appropriately held accountable? Could the state be deemed responsible for "inviting" a (private) political party to make racially discriminatory membership decisions? No such complications existed in Herndon, however, because the Texas statute, not a party rule, barred black participation in party primaries. Justice Holmes, writing for the Court, saw this as an easy issue. In his two-page opinion, he declined to reach the Fifteenth Amendment question because "it

10. Grovey v. Townsend, 295 U.S. 45 (1935); Nixon v. Condon, 286 U.S. 73 (1932); Nixon v. Herndon, 273 U.S. 536 (1927); see also Love v. Griffith, 266 U.S. 32, 34 (1924) (rejecting initial challenge to the Texas white primary on mootness grounds). For the most extensive treatment of the white primary litigation, see DARLENE CLARK HINE, BLACK Victory: The RISE AND FAll of the White PRIMARY IN TeXAS (1979). For other helpful treatments, see Richard Kluger, Simple Justice: The History of BROWN V. BOARD OF EDUCATION AND BLACK AMERICA'S STRUGGLE FOR EQUALITY 137-39, 233-38 (1976); STEVEN F. LAWSON, Black BALlots: Voting Rights IN THE SOUth 1944-1969, at 23-54 (1976); Charles S. Mangum, JR., The Legal Status of the Negro 405-24 (1940); Bernard H. Nelson, The Fourteenth Amendment And the Negro Since 1920, at 34-41, 85-106 (1946); Robert Wendell Hainsworth, The Negro and the Texas Primaries, 18 J. NegRO HIST. 426 (1933).

11. 273 U.S. $536(1927)$.

12. E.g., James v. Bowman, 190 U.S. 127, 136 (1903) (Fifteenth Amendment); Civil Rights Cases, 109 U.S. 3, 11 (1883) (Fourteenth Amendment). 
seems to us hard to imagine a more direct and obvious infringement of the Fourteenth."13

Yet Herndon was severely limited in its implications. The Texas white primary statute was the only one of its kind in the nation. ${ }^{14}$ In other Southern states, blacks were excluded from Democratic primaries by party rule, not by state statute. Herndon did not necessarily have any implications for the constitutionality of these other permutations of the white primary. Thus, the decision was a quintessential example of constitutional law's proclivity for suppressing outliers. ${ }^{15}$

In its subsequent white primary cases, stretching from Nixon $v$. Condon $^{16}$ in 1932 to Terry v. Adams ${ }^{17}$ in 1953, the Court had to confront the intractable state action issue. After Herndon, the Texas legislature immediately enacted a law empowering the executive committee of political parties to prescribe qualifications for membership. ${ }^{18}$ As anticipated and intended, the executive committee of the Texas State Democratic Party quickly passed a resolution excluding blacks from party membership. ${ }^{19}$ The issue in Condon was whether the state properly could be held responsible for the racially discriminatory actions of the party. By the same five-to-four vote that frequently divided the Justices along liberal/conservative lines on economic issues in the $1930 \mathrm{~s},{ }^{20}$ the Court in Condon found discriminatory state action on the ground that the Texas legislature, rather than the State Democratic Party, had reposed authority in the party executive committee to prescribe membership qualifications. ${ }^{21}$ The majority declined to reach the question of whether a political party's exclusion of blacks would qualify as state action in the absence of a

13. Herndon, 273 U.S. at 541.

14. On the novelty and origins of the Texas statute, see HINE, supra note 10, at 47-49; LAWSON, supra note 10, at 24-25; NELSON, supra note 10, at 36-37; Leo Alilunas, Legal Restrictions on the Negro in Politics, 25 J. NEGRo HIST. 153, 167, 172-73 (1940); O. Douglas Weeks, The White Primary, 8 Miss. L.J. 135, 138 (1935).

15. On the notion that the Supreme Court's constitutional rulings frequently involve suppression of outlier practice, see Michael J. Klarman, Rethinking the Civil Rights and Civil Liberties Revolutions, 82 VA. L. REV. 1, 16-18 (1996); Michael J. Klarman, Rethinking the History of American Freedom, 42 WM. \& MARY L. REV. 265, 279 nn.60-65 (2000) (book review). On the notion that Jim Crow statutes frequently reflected rather than fostered Jim Crow norms, see Michael J. Klarman, The Plessy Era, 1998 SuP. CT. REv. 303, 390-91, 397-99, 401-02 (1998) [hereinafter Klarman, Plessy].

16. 286 U.S. 73 (1932).

17. 345 U.S. 461 (1953).

18. HINE, supra note 10 , at 109-11.

19. Condon, 286 U.S. at 82.

20. E.g., W. Coast Hotel Co. v. Parrish, 300 U.S. 379 (1937) (minimum wage law); Nebbia v. New York, 291 U.S. 502 (1934) (price regulation); Home Bldg. \& Loan Ass'n v. Blaisdell, 290 U.S. 398 (1934) (mortgage moratorium). Barry Cushman has properly cautioned against the casual use of political labels to describe the New Deal Justices. Barry Cushman, The Secret Lives of the Four Horsemen, 83 VA. L. REV. 559 (1997).

21. Condon, 286 U.S. at 88-89. 
statute specifying which decisionmaking entity within the party was responsible for determining membership qualifications. ${ }^{22}$

Condon's principal effect was to defer the more fundamental state action issue for an additional three years. The unresolved question was whether the Constitution prevented a political party from excluding blacks from membership when the state had not altered the party's "natural" decisionmaking apparatus. Just three weeks after Condon, the annual convention of the Texas State Democratic Party passed a resolution barring blacks from membership..$^{23}$ Condon's rationale for invalidating the white primary had disappeared-the party had acted on its own, free from state influence over its decisionmaking processes. The Court now had to confront directly the question of whether the state was constitutionally responsible for a political party's independent decision to bar blacks from membership. In Grovey v. Townsend, ${ }^{24}$ the Justices unanimously declined to find state action under those circumstances.

Grovey is a confused and confusing opinion. Justice Roberts conceded all the ways in which the state had regulated party primaries. ${ }^{25}$ For example, Texas laws required that primary elections be held, that voter qualifications for general elections be applicable in primaries, that absentee voting be permitted, and that election judges enjoy certain specified powers. ${ }^{26}$ Justice Roberts identified two differences between primary and general elections that informed the Court's determination that the exclusion of blacks from Democratic Party primaries was not state action: the state neither paid the expenses of the primary, nor did it furnish or count the ballots. ${ }^{27}$ Lower court decisions considering the constitutionality of the white primary often had focused on these same factors. ${ }^{28}$ But neither Justice Roberts nor these lower court judges satisfactorily explained why certain forms of state involvement in primary elections, but not others, constituted the state action necessary to implicate the Fourteenth or Fifteenth Amendments.

22. Id. at 83 .

23. LAWSON, supra note 10 , at 31 .

24. 295 U.S. 45 (1935).

25. Id. at $49-53$.

26. Id. at 49 .

27. $I d$. at 50 .

28. Nixon v. Condon, 34 F.2d 464 (W.D. Tex. 1929), aff'd, 49 F.2d 1012 (5th Cir. 1931); West v. Bliley, 33 F.2d 177 (E.D. Va. 1929), aff'd, 42 F.2d 101 (4th Cir. 1930); Robinson v. Holman, 26 S.W.2d 66 (Ark. 1930); White v. Lubbock, 30 S.W.2d 722 (Tex. Civ. App. 1930). For commentary on these lower court decisions, see Editorial, RICHMOND TIMES-DISPATCH, Apr. 3, 1935, at 8, reprinted in The AtTITUde of THE Southern White PREss Toward Negro Suffrage, 1932-1940, at 111 (Rayford W. Logan ed., 1940); Hine, supra note 10, ch. 5; Paul Lewinson, Race, Class, and Party: A History of Negro Suffrage and White Politics IN THE SOUTH 155-56 (1932); MANGUM, supra note 10, at 414-16; Weeks, supra note 14 , at $144-45,153$. 
Herndon and Condon had little, if any, direct impact on black voting in the South because they were so easily circumvented. Herndon had no application outside of Texas, which was the only state to bar blacks from participating in party primaries by statute. Public reaction to the decision in Texas was nonchalant because black exclusion from party primaries could be accomplished just as easily through party rule as by state statute. ${ }^{29}$ Similarly, Condon proved insignificant because it simply rerouted the decision to exclude blacks from the party's executive committee to its annual state convention. It is difficult to comprehend why either ruling would have induced Southern state Democratic parties to permit blacks to participate in their primaries.

Grovey upheld the white primary when it was adopted by party convention, so obviously it did not lead to any increase in Southernern black political participation. Interestingly, neither did two lower court decisions in the early 1930s, which invalidated the white Democratic primaries of Virginia and Florida. In both of those states, the government paid for primary elections, unlike in Texas, where the party underwrote the expense. Two lower courts considered this difference dispositive and invalidated the white primaries in those states. ${ }^{30}$ Yet black voter registration increased very little in Virginia and Florida after these rulings, and in the rural counties of those states, officials completely ignored the decisions. ${ }^{31}$ Charles Hamilton Houston of the NAACP drew the lesson from these cases that successful litigation accomplished little unless local communities were prepared to act upon favorable court rulings. ${ }^{32}$ Social and political conditions in the South were not yet ripe in the 1930s for mobilizing the African-American community for effective implementation of litigation victories. Indeed, had these court decisions invalidating white primaries in Virginia and Florida had a more significant impact on black voter registration, state legislatures probably would have transferred financial responsibility for primary elections from the government to political parties in order to insulate the white primary from constitutional challenge. Because the rulings had such little consequence, nobody took steps to circumvent them.

29. See, e.g., NELSON, supra note 10, at 39. On Herndon's limited overall impact, see id. at $85-86$.

30. Bliley v. West, 42 F.2d 101 (4th Cir. 1930); Goode v. Johnson, 149 So. 736 (Fla 1933).

31. On the limited impact of these decisions, see RALPH J. Bunche, ThE POLITICAL StATUs OF THE NEGRo IN THE AGE OF FDR 442 (Dewey W. Grantham ed., 1973); Hine, supra note 10, at 95-96, 101. But cf. LEWINSON, supra note 28, at 156 (noting that after the Fourth Circuit decision in Bliley, "there was a noticeable tendency, at least in the larger cities of Virginia, to admit Negroes to the State primaries ....”).

32. Alan Robert Burch, The NAACP Before and After Grovey v. Townsend 72-73 (1994) (unpublished master's thesis, University of Virginia) (on file with author). 


\section{The Legal And Political Context of SMITH V. ALLWRIGHT AND THE SUbSEqUENT History OF THE White PRIMARY}

Although Grovey v. Townsend was unanimous, the NAACP never regarded it as "completely fatal" and persisted in trying to persuade the Justices to reconsider their decision. ${ }^{33}$ Before the NAACP could carry another white primary case to the Court, however, an intervening decision on a related issue raised hopes that the Justices might reconsider Grovey. United States v. Classic, ${ }^{34}$ decided in 1941, raised the question of whether the Federal Government had the constitutional power to punish fraud in primary elections for national offices. Article I, section 4 of the Constitution empowers Congress to regulate "The Times, Places and Manner of holding Elections for Senators and Representatives . . . ." 35 In Newberry v. United States, ${ }^{36}$ decided in 1921, a splintered Court had ruled that this constitutional provision did not authorize Congress to regulate primary elections for the United States Senate on the ground that primaries were not "Elections" within the meaning of Article I, section $4 .^{37}$ In Classic, the Court overruled Newberry and sustained the Federal Government's power to prosecute Louisiana election commissioners who had committed fraud during a primary election for a seat in the United States Congress.

The Court in Classic took care not to impeach the continuing validity of Grovey. The government brief in Classic distinguished Grovey, rather than asking the Court to overrule it, and Justice Stone's majority opinion made no mention whatsoever of Grovey. ${ }^{38}$ The two cases are indeed distinguishable, and in more than one way. First, Louisiana and Texas laws regulated party primaries differently, and thus it was possible to identify state action in one case without finding it in the other. Specifically, Louisiana law required that parties conduct primaries if they wanted their candidates to ap-

33. Letter from Charles H. Houston to R.D. Evans (Mar. 9, 1938), microformed on NAACP Papers, pt. IV, reel 3, fr. 366. Documents from the NAACP Papers, cited throughout this Article, can be found in a Microfilm Edition at libraries across the United States. A permanent collection with a different numbering system also can be found at the Library of Congress's Manuscript Division in Washington, D.C.

34. 313 U.S. 299 (1941). Classic is discussed in RoBert K. CARR, FEDERAL Protection of Civil Rights: Quest For A Sword 85-120 (1947); David M. Bixby, The Roosevelt Court, Democratic Ideology and Minority Rights: Another Look at United States v. Classic, 90 YALE L.J. 741, 792-815 (1981).

35. U.S. CONST. art. I, § 4, cl. 1.

36. 256 U.S. 232 (1921). Newberry is discussed in Benno C. Schmidt, Jr., Principle and Prejudice: The Supreme Court and Race in the Progressive Era, Part 3: Black Disfranchisement from the KKK to the Grandfather Clause, 82 COLUM. L. REV. 835, 887-98 (1982).

37. Newberry, 256 U.S. at 249-50.

38. For the government's brief in Classic, see LAWSON, supra note 10, at 40. 
pear on the general election ballot, while Texas law did not. ${ }^{39}$ Also, Louisiana paid the cost of party primaries, ${ }^{40}$ while Texas did not. ${ }^{41}$

Second, Grovey involved the question of whether party regulation of primaries constituted state action under the Fourteenth or Fifteenth Amendments, while Classic raised the issue of whether primaries were "Elections" under Article I, section 4. These two questions need not yield the same answer. The Court had long held, for example, that under Article I, section 4, Congress could regulate individual action interfering with the right to vote in federal elections. ${ }^{42}$ Yet it had simultaneously denied Congress the power under the enforcement sections of the Fourteenth and Fifteenth Amendments to prohibit individual action interfering with the rights of blacks. ${ }^{43}$ Given that the Court had imposed a state action requirement for congressional regulation under the Reconstruction Amendments but not under Article I, section 4, it was perfectly conceivable that the Justices would treat primary elections differently under these two constitutional provisions. Thus, Classic in no sense mandated the overthrow of Grovey.

On the other hand, much of the Court's reasoning in Classic seemed directly relevant to the constitutionality of the white primary under the Reconstruction Amendments. In holding that a party primary was an "Election" under Article I, section 4, the Court emphasized a variety of factors that would seem equally relevant to the state action issue under the Fourteenth and Fifteenth Amendments: ${ }^{44}$ Louisiana paid the costs of the primary; state law required that party candidates on the general election ballot be selected through primaries; state law regulated the time, place, and manner of the primary election; and finally, as a practical matter, the primary election result determined the outcome of the general election in the one-party state of Louisiana. Lower courts and the Supreme Court previously had considered precisely the same sorts of factors in deciding whether party rules excluding blacks from primary elections amounted to unconstitutional state action under the Fourteenth or Fifteenth Amendments. ${ }^{45}$ Assuming that the factors enumerated in Classic would indeed prove relevant to the Court's future determination of the constitutionality of white primaries under the Reconstruction Amendments, the critical question became how to interpret the following passage from Classic: Constitutional rights were implicated

39. Classic, 313 U.S. at 312-13.

40. Id. at 311 .

41. Grovey v. Townsend, 295 U.S. 45, 50 (1935).

42. E.g., Ex parte Yarbrough, 110 U.S. 651, 661-62 (1884).

43. See supra note 12 .

44. Classic, 313 U.S. at 318-20.

45. See supra note 28 and accompanying text. 
in primary elections "[w]here the state law has made the primary an integral part of the procedure of choice, or where in fact the primary effectively controls the choice." 46 Throughout the one-party South in the 1940s, Democratic primaries "effectively control[led] the choice" at the general election. Yet different states regulated primaries differently, and nobody could be certain what it meant for state law to make the primary "an integral part of the procedure of choice." 47

Many contemporary commentators were convinced that Classic had implications for the white primary, ${ }^{48}$ and Justice Harlan Fiske Stone later wrote that he had considered Grovey doomed from the moment he penned the majority opinion in Classic. ${ }^{49}$ NAACP lawyers were among those observers who were confident that the days of the white primary were numbered after Classic. ${ }^{50}$ Yet it surely would have been possible for the Justices to leave Grovey in place after Classic, had they been inclined to do so, either by distinguishing Texas law from Louisiana law or by distinguishing the Article I question from that raised under the Fourteenth and Fifteenth Amendments. Lower court judges, for example, plainly did not believe that Grovey had been (silently) overruled by Classic. ${ }^{51}$

Just a couple of years later, however, the Justices granted certiorari in Smith v. Allwright to reconcile "a claimed inconsistency" between Grovey and Classic-an inconsistency that somehow had escaped their attention when they decided the latter. ${ }^{52}$ By an eight-toone vote, the Court overruled Grovey, observing, among other things, that the rule of stare decisis carries reduced weight in constitutional cases. ${ }^{53}$ Justice Reed's majority opinion, noting that "[t]he party takes its character as a state agency from the duties imposed upon it by state statutes," ${ }^{4}$ emphasized the multiplicity of ways in which Texas law regulated the state Democratic Party and its primariesfor example, requiring that primary elections be held at particular

46. Classic, 313 U.S. at 318.

47. On alternative ways to read Classic, see Bixby, supra note 34, at 803-05.

48. For contemporary predictions after Classic that the Court would overrule Grovey, see Virginius DabneY, Below the PotomaC: A BooK About the NeW South 197 (1942); Fred G. Folsom, Jr., Federal Elections and the "White Primary", 43 Colum. L. REv. 1026, 1027-28, 1033-35 (1943); see also Bixby, supra note 34, at 803-04 (noting that both contemporary commentators and the Justices seemed to appreciate the implications of Classic for the white primary issue).

49. Bixby, supra note 34 , at 803-04.

50. See, e.g., HINE, supra note 10, at 205-07, 213-14 (describing the views of Thurgood Marshall and the NAACP).

51. See, e.g., Smith v. Allwright, 131 F.2d 593 (5th Cir. 1942) (per curiam) (affirming a lower court decision that had rejected a constitutional challenge to the Texas white primary, Classic notwithstanding).

52. 321 U.S. 649, 652 (1944). For background on Smith, see HINE, supra note 10, ch. 10; LAWSON, supra note 10, ch. 2.

53. Smith, 321 U.S. at $665-66$.

54. Id. at 663 . 
times, conducted in certain manners, and subjected to state oversight. ${ }^{55}$ The Court also emphasized what appeared to be a logically separate point: that primaries had "become a part of the machinery for choosing officials" and that Texas could not escape responsibility by "casting its electoral process in a form which permits a private organization to practice racial discrimination in the election." ${ }^{56}$ These latter phrases raised the possibility that the Court might deem party primaries to be state action, regardless of how state law regulated them.

The shift from a nine-to-zero ruling in Grovey to an eight-to-one decision overruling it in Smith, within just a nine-year period, is unprecedented in Supreme Court history. It is tempting to attribute this turnabout to President Roosevelt's virtually complete recomposition of the Court during the intervening years. Only one JusticeHarlan Fiske Stone-changed his mind in the interim. The only other surviving member of the Grovey Court was the decision's author, Justice Owen Roberts. He penned a bitter dissent in Smith, lamenting the Stone Court's propensity for overruling precedents, ${ }^{57}$ which "tends to bring adjudications of this tribunal into the same class as a restricted railroad ticket, good for this day and train only." 58

Focusing on the Court's recomposition as the explanation for the result in Smith, though, misses something more fundamental-the significance of World War II. This is necessarily a point of speculation because nothing in the Smith opinion or the surviving conference notes refers to the significance of the war. Still, the Justices cannot have failed to observe the tension between a purportedly democratic war fought against the Nazis, with their theories of Aryan supremacy, and the pervasive disfranchisement of Southern blacks. With black soldiers "dying just as same as the white," 59 the Justices must have felt tempted to do their part in ameliorating the hypocrisy of America's democratic pretensions. As the New York Times approvingly noted the day after Smith, the ruling put America "a little nearer to a more perfect democracy, in which there will be but one class of citizens ...."60 Around the same time as Smith, Congress debated both a general repeal of the poll tax in federal elections and a more limited bill to suspend poll tax payments in federal elections for

55. Id. at $662-64$

56. Id. at 664 .

57. On the rising number of dissents, see C. HERMAn PRITCHETt, THE Roosevelt CourT: A STUdy IN JUdicial POLITICS AND VAlues 1937-1947, at 23, 25 tbl.1 (1948).

58. Smith, 321 U.S. at 669 (Roberts, J., dissenting).

59. Letter from anonymous correspondent in Gurdon, Ark., to NAACP (July 16, 1944), microformed on NAACP Papers, pt. IV, reel 6, fr. 682.

60. Primaries Are Not Private, N.Y. TIMES, Apr. 5, 1944, at 18. 
members of the armed services. ${ }^{61}$ The same democratic ideology that inspired Congress to consider these measures probably influenced the Justices' thinking about the white primary. The one decisive difference between Congress and the Court, however, was that the Southern Democrats' stranglehold over the former (the Senate, specifically) did not extend to the latter. The bill to repeal the poll tax failed in the Senate at the same time the Court was interring the white primary. ${ }^{62}$

Another reason Smith may have proven a relatively easy decision for the Justices-if not as a matter of law, at least as a matter of policy-was that most Americans would have endorsed the result. The best evidence for this proposition involves Northern attitudes on an analogous issue-federal legislation to repeal the poll tax. The voting patterns of Northern congressmen suggest overwhelming support in Northern opinion for abolition of this other set of peculiarly Southern suffrage restrictions. ${ }^{63}$ There is no reason to think that most northerners would have felt differently about white primaries and poll taxes. Both of these suffrage restrictions applied only in seven or eight Southern states by the mid-1940s. ${ }^{64}$ Moreover, even Southern whites evinced significantly less commitment to preserving white political supremacy than, for example, to maintaining racial segregation in public education. That is, black disfranchisement ranked relatively low on the hierarchy of white supremacist convictions. ${ }^{65}$ This may explain why Kentuckian Stanley Reed apparently had no qualms about writing the majority opinion in Smith, whereas in Brown v. Board of Education he planned to dissent until virtually the last minute. ${ }^{66}$

61. On poll tax repeal, see LAWSON, supra note 10, at 65-66, 72-75.

62. Frederic D. OGden, The Poll TAX IN The South 247 (1958).

63. LAWSON, supra note 10 , at $58,68-70$.

64. Eight Southern states still employed a poll tax as a suffrage qualification in 1944: Alabama, Arkansas, Georgia, Mississippi, South Carolina, Tennessee, Texas, and Virginia. OGDEN, supra note 62, at 185-201. These same states also conducted white primaries, although in Tennessee only in certain counties, not at the state level. North Carolina, which had eliminated its poll tax in 1920, likewise continued to use a white primary only in certain counties.

65. See Gunnar Myrdal, An American Dilemma: The Negro Problem and MODERN DEMOCRACY 60-61, 587-88 (1944); see also LAWSON, supra note 10, at 22 (noting that black disfranchisement fell near the bottom of the white southerners' hierarchy of racial preferences); $c f$. Thomas A. Krueger, And Promises to Keep: The Southern CONFERENCE FOR HUMAN WELFARE, 1938-1948, at 128 (1967) (noting that the Southern Conference for Human Welfare secured a public statement signed by several hundred southerners in support of Smith).

66. For Reed's position in Brown, see KLUGER, supra note 10, at 595-96, 655-56, 680, 698. On Reed's racial views generally, which clearly sympathized with segregation, see John D. Fassett, New Deal Justice: The Life of Stanley ReEd of KentuCKy 555-80 (1994). 
Smith was not, as Thurgood Marshall claimed, "so clear and free of ambiguity" that it settled "once and for all" the right of blacks to participate in party primaries. ${ }^{67}$ To the contrary, ambiguity in the Smith opinion virtually invited efforts at circumvention. ${ }^{68}$ Specifically, to the extent that Smith turned on the fact that Texas law extensively regulated the state Democratic Party and its primaries, the Court's ruling naturally led Southern states to consider deregulation as a response. South Carolina wasted no time. ${ }^{69}$ Within a fortnight of Smith, Governor Olin Johnston convened a special session of the state legislature and successfully urged the repeal of all 150 state statutes regulating political parties. ${ }^{70}$ Other Deep South states evinced considerable enthusiasm for following suit but instead adopted a wait-and-see posture as lower federal courts wrestled with South Carolina's efforts to circumvent Smith. ${ }^{71}$

In 1947, in Elmore v. Rice, ${ }^{72}$ a South Carolina Federal District Judge, J. Waties Waring, ruled that the State Democratic Party's exclusion of blacks was unconstitutional state action, notwithstanding the legislature's recent deregulation of the party. Under Classic, the constitutional ramifications of party primaries had turned on either of two factors-whether "state law has made the primary an integral part of the procedure of choice" or whether "in fact the primary effectively controls the choice." ${ }^{3}$ While legislative deregulation arguably had removed the former rationale for finding state action in the South Carolina Democratic Party's exclusion of blacks, the latter consideration remained fully applicable. ${ }^{74}$ For example, in seven of the previous eight presidential elections, the Republican candidate

67. LAWSON, supra note 10 , at 46 .

68. See, e.g., James D. Barnett, Note \& Comment, 23 OR. L. REV. 264, 267 (1944); Note, Negro Disenfranchisement-A Challenge to the Constitution, 47 ColuM. L. REv. 76, 81 (1947) [hereinafter Negro Disenfranchisement] (noting that Smith itself "suggested new means of evasion").

69. On South Carolina's response, see LAWSON, supra note 10, at 49-50; PATRICIA Sullivan, Days of Hope: RACE AND Democracy IN the New DeAl ERA 169-70 (1996); N.Y. TIMES, Apr. 18, 1944, at 13.

70. On Governor Johnston's message to the special legislative session on April 14, 1944, see infra notes 240-44 and accompanying text.

71. See, e.g., John N. Popham, Negro Vote Battle Looms in Alabama, N.Y. TIMES, Mar. 3, 1947, at 44 (Alabama); Democratic Vote of Negroes Upheld, N.Y Times, July 28, 1945, at 24 (Tallahassee); Letter from William P. Baskin to Herman Talmadge (May 16, 1947), microformed on NAACP Papers, pt. IV, reel 9, frs. 983-84 (Georgia); Letter from A.T. Walden to Francis J. Biddle (March 18, 1945), id. pt. IV, reel 7, fr. 637 (Atlanta); Frank Chappell, State Demo Chairmen Set Dallas Meet, DAily Times Herald (Jan. 29, 1947), id. pt. IV, reel 8, fr. 194 (Texas); Letter from John H. McCray to Oliver W. Harrington (Jan. 18, 1947), id. pt. IV, reel 10, fr. 850; Letter from Thurgood Marshall to Thurman Arnold (Apr. 7, 1947), id. pt. IV, reel 10, fr. 875.

72. 72 F. Supp. 516 (E.D.S.C. 1947), aff'd, 165 F.2d 387 (4th Cir. 1947).

73. United States v. Classic, 313 U.S. 299, 318 (1941).

74. For useful commentary on the constitutional issue raised in Elmore, see Negro Disenfranchisement, supra note 68 , at 80-90. 
had won less than five percent of the popular vote in South Carolina; ${ }^{75}$ thus, the Democratic Party primary clearly "control[led] the choice" at the general election. In his opinion invalidating the South Carolina Democratic Party's exclusion of blacks, Judge Waring emphasized both the extent to which state law had regulated political parties prior to deregulation and the Democratic Party's historical domination of election results in South Carolina. ${ }^{76}$ Waring considered it "pure sophistry" to suggest that the legislature's deregulation efforts had made any material difference to political realities in South Carolina, and he denied that "the skies will fall" if the State Democratic Party permitted blacks to participate in its primaries. ${ }^{77}$ Invoking the Cold War imperative for racial change as a partial justification for his ruling ${ }^{78}$ Waring declared "[i]t is time for South Carolina to rejoin the Union." "79 The Fourth Circuit affirmed Judge Waring in a less flamboyant opinion. ${ }^{80}$ The Supreme Court, probably delighted to have Southern judges running interference on such a politically sensitive racial issue, denied review. ${ }^{81}$ South Carolina's efforts to evade Smith had "received a complete and shattering defeat." ${ }^{2}$ Other Deep South states now abandoned consideration of the deregulation option. ${ }^{83}$

Yet even Elmore did not, as Marshall had hoped, nail down the lid in "the coffin of the white primary." ${ }^{44}$ One more iteration of the white primary remained for the Court's consideration. In Fort Bend County, Texas, the Jaybird Democratic Association had been excluding blacks from its pre-primary selection of candidates since $1889 .{ }^{85}$ The Association, a political club consisting of all whites in the county, selected candidates for office who invariably became the Democratic Party nominees. Then, just as invariably, the nominees triumphed in

75. Election results in Preliminary Memorandum regarding Primaries in South Carolina and Georgia (Feb. 10, 1947), microformed on NAACP Papers, pt. IV, reel 10, fr. 470.

76. Elmore, 72 F. Supp. at 523.

77. Id. at 527 .

78. The Cold War imperative for racial change was the notion that America must alter its racial attitudes and practices to defuse Soviet propaganda and convince the nonwhite nations of Africa and Asia that democratic capitalism was not synonymous with white supremacy. For the most extensive documentation of the Cold War imperative, see MARY L. DUdZIAK, COLD WAR CIVIL Rights: RACE AND THE IMAGE OF AMERICAN DEMOCRACY (2000).

79. $\quad$ Elmore, 72 F. Supp. at 528.

80. Rice v. Elmore, 165 F.2d 387 (4th Cir. 1947).

81. Rice v. Elmore, 333 U.S. 875 (1948).

82. The Right to Vote, 4 NEW SOUTH 1, 3 (Feb. 1949), microformed on NAACP Papers, pt. IV, reel 7, frs. 554, 556 [hereinafter The Right to Vote]. fr. 209.

83. See Letter from Thurgood Marshall to C.A. Scott (Sept. 23, 1947), id. pt. IV, reel 8,

84. Letter from William H. Hastie to Thurgood Marshall (July 19, 1947), id. pt. IV, reel 9, frs. 900-01; see also Letter from Thurgood Marshall to William H. Hastie (July 22, 1947), id. pt. IV, reel 9, frs. 902-03 (confirming Hastie's estimation of the effect of Elmore).

85. Terry v. Adams, 345 U.S. 461, 463 (1952). 
the general election. Other East Texas counties operated similar exclusionary schemes, some dating back as far as the late $1870 \mathrm{~s}^{86}$ While the Jaybirds did not create their Association to circumvent Smith and Elmore, they may just as well have, since it is easy to imagine the rest of the South following suit if the Court had sustained the constitutionality of this scheme. The Justices thus had a strong incentive to invalidate the Jaybirds' pre-primary. At conference, they evinced concern that "if this [scheme] is approved, it will be seized upon" and that to allow the Jaybirds' pre-primary "would practically overturn the previous cases." ${ }^{\prime 7}$

In Terry $v$. Adams ${ }^{88}$ the Justices, by an eight-to-one vote, interred the Jaybirds' "hateful little local scheme," though some of them belived that they sacrificed "sound principle[s] of interpretation" in doing so. ${ }^{89}$ None of the rationales articulated by the three separate opinions in support of the conclusion that the Jaybirds' scheme involved the requisite state action for a constitutional violation was terribly persuasive. ${ }^{90}$ The principal difficulty for the Justices involved drawing a line between the Jaybirds' discriminatory political scheme (which the Court ruled unconstitutional under the Fifteenth Amendment), and the discriminatory political preferences of private individuals (which not only fail to violate the Constitution, but actually receive affirmative protection under the First Amendment). The Court's inability to articulate a principle distinguishing the unconstitutional Jaybird pre-primary from constitutionally protected private discriminatory preferences led Justice Minton, the sole dissenter, to charge in a note to Justice Jackson that "[w]hen the Jaybird opinion comes down, there may be some question as to which election returns the Court follows! It will be damn clear they aren't

86. Hine, supra note 10, at 27-29; LAWREnce D. RiCe, The Negro IN TEXAS 18741900, at 118 (1971); see also J. Austin Burkhart, The White Man's Primary, 56 THE CRISIS 81, 81-82 (March 1949) (noting a similar exclusionary scheme in Grimes County, Texas); id. at 191-92 (March 1951) (noting a circuit court decision in Harrison County, Texas, which refused to permit the exclusion of blacks from the "Citizens Party," an organization that effectively had controlled the outcome of county primary elections for the past fifty years).

87. Justices Black and Clark, respectively, quoted in 2 DELAVAN DiCKson, THE SUPREME COURT IN CONFERENCE: 1940-1985, at 838-40 (2001).

88. 345 U.S. at 471.

89. Robert H. Jackson, Draft Dissent, Terry v. Adams 1, 9 (Apr. 3, 1953) (Robert Jackson papers, Collections of the Manuscript Division, Library of Congress, Box 179, Case No.52).

90. For discussion and criticism of the Terry opinions, see Michael J. Klarman, Neither Hero, Nor Villain: The Supreme Court, Race, and the Constitution in the Twentieth Century. Chapter Four: The World War II Era 33-36 (unpublished manuscript, on file with author); see also SAmuel Issacharoff, Pamela S. Karlan \& Richard H. Pildes, The LaW of Democracy: Legal Structure of the Political Process 93-95 (1998) (raising questions about the meaning and implications of Terry). 
following any law." ${ }^{11}$ In the same year that they pondered the invalidation of racial segregation in public education, the Justices displayed an unwillingness to legitimize a Southern community's scheme for disfranchising blacks, regardless of how strained the constitutional rationale for invalidating it.

\section{The Consequences of SMITH V. ALLWRIGHT}

In 1940, just three percent of eligible Southern blacks were registered to vote, but by 1952 twenty percent were. ${ }^{92}$ Some of that increase preceded Smith and therefore must be attributed to various factors associated with World War II, rather than to the Court's intervention. ${ }^{93}$ Nor can one attribute all of the post-1944 increase in Southern black voter registration to Smith. Yet the Court's invalidation of the white primary contributed significantly to the dramatic increase in Southern black voter registration that took place in the middle and late 1940s. Why Smith should have had this effect is an interesting question, given that lower court decisions in the early 1930s invalidating the white primaries of Virginia and Florida did not. ${ }^{94}$

Numerous changes in the Southern social and political climate enabled Smith to have such a notable impact. The most important of these were the following: an increased willingness among white Southerners to tolerate black political participation; the greater assertiveness of Southern blacks in demanding their rights; the proliferation of NAACP branches in the South, which facilitated legal challenges to efforts at nullifying Smith; an increased threat of Justice Department prosecution of persons continuing to obstruct black suffrage; and the unprecedented willingness of Southern judges to generously construe black voting rights. Together, these factors created an environment in which the Court's invalidation of the white primary launched a political revolution in the urban South. Without these propitious background circumstances, Smith likely would have

91. Letter from Sherman Minton to Robert Jackson (March 28, 1953), quoted in MARK V. Tushnet, Making Civil Rights LaW: Thurgood MARShall and the Supreme CourT, 1936-1961, at 112 (1994).

92. David J. Garrow, Protest at Selma: Martin Luther King, JR., and the Voting RIGHTS ACT OF 1965, at 7 tbl.1-1, 11 tbl.1-2 (1978); LAWSON, supra note 10, at 284 tbl.1.

93. For blacks trying to register to vote or to participate in Democratic Party primaries before Smith, see, for example, Letter from Donald Jones to Thurgood Marshall (Aug. 10, 1942), microformed on NAACP Papers, pt. IV, reel 8, fr. 387; Letter from Bennett B. Ross to Walter White (Aug. 22, 1942), id. pt. IV, reel 8, fr. 389; Letter from Carsie A. Hall to Thurgood Marshall (Aug. 26, 1942), id. pt. IV, reel 8, fr. 797; Letter from W.R. Saxon to Thurgood Marshall (Mar. 15, 1941), id. pt. IV, reel 9, fr. 151. I have described at some length the variety of ways in which World War II contributed to changes in American racial attitudes and practices. See generally Klarman, supra note 90.

94. See supra note 31. 
been almost as inconsequential as earlier voting rights decisions, such as Guinn v. United States ${ }^{95}$ and Nixon v. Herndon. ${ }^{96}$ Each of these factors warrants a closer look, though first we should consider briefly the immediate impact of Smith on the South.

In states like Tennessee and North Carolina, which never had conducted statewide white primaries, and Virginia, where federal courts had invalidated the white primary over a decade earlier, white reaction to Smith proved mostly calm and collected. ${ }^{97}$ The two leading Richmond newspapers, for example, endorsed the ruling. One of them observed that blacks had voted in Virginia's Democratic primaries for years, yet "the skies haven't fallen."98 Moreover, in Arkansas and Texas-states which had barred black participation in Democratic primaries prior to Smith-many counties immediately dismantled racial barriers after the Court's ruling. ${ }^{99}$ In the Deep South, however, Democratic Party officials and officeholders pledged resistance. Party committees in Florida, Georgia, South Carolina, Alabama, Louisiana, and Mississippi resolved to maintain their racial exclusivity, and blacks in those states generally were not permitted to vote in primaries in the spring and summer of $1944 .{ }^{100}$ That year, only an estimated 200,000 Southern blacks were registered to vote, overwhelmingly as Republicans. ${ }^{101}$

Within just a couple of years, however, huge changes took place. Blacks participated in large numbers in Democratic primaries in Georgia, Florida, and Texas by 1946, in Louisiana and South Carolina by 1948, and even in Mississippi by 1950. The number of Southern blacks registered to vote rose to between 700,000 and 800,000 by

95. 238 U.S. 347 (1915) (invalidating the grandfather clause); see also Klarman, Progressive Era, supra note 7, at 919-21 (noting that Guinn had essentially no impact on black disfranchisement).

96. 273 U.S. 536 (1927). On Herndon's lack of concrete significance, see supra note 29 and accompanying text.

97. See, e.g., Southern Leaders Prepare to Resist, N.Y. TIMES, Apr. 4, 1944, at 15; Dixie Vote (unidentified and undated press clipping), microformed on NAACP Papers, pt. IV, reel 7, fr. 583; see also Court Decision No Impasse, ATLANTA Const. (Apr. 5, 1944), id. pt. IV, reel 7, fr. 585 (urging calm, noting that several states already allowed blacks to vote in Democratic Party primaries, and observing that blacks obviously would not be permitted to exercise political control in the Deep South); Letter from B.R. Edmunds to NAACP (Dec. 2, 1944), id. pt. IV, reel 7, fr. 424 (observing that blacks already could vote freely in most parts of Virginia, North Carolina, Kentucky, Tennessee, and Oklahoma).

98. Richmond Times Dispatch, quoted in HINE, supra note 10, at 224.

99. Letter from Thurgood Marshall to A.T. Walden (July 26, 1944), microformed on NAACP Papers, pt. IV, reel 7, frs. 620-21.

100. See infra notes 231-32 and accompanying text.

101. For estimates on black voter registration, see Memorandum from Palmer Weber to Thurgood Marshall et al., Citizenship in the South (Nov. 8, 1948), microformed on NAACP Papers, pt. IV, reel 7, frs. 549-53 [hereinafter Weber, Citizenship]. 
1948 and then to one million by $1952 .{ }^{102}$ Georgia experienced the quickest and most startling transformation-black voter registration increased from roughly 20,000 in 1940 to 125,000 in $1947 .{ }^{103}$ In South Carolina, where essentially no blacks were permitted to vote in Democratic primaries in 1946, an estimated 35,000 participated in 1948. ${ }^{104}$ That same year, the number of registered black voters in Louisiana increased from 8,000 to 43,000 within an eight-month period; by 1952 , the number had grown to $107,000 .{ }^{105}$ In Florida, the number of registered black voters increased from 49,000 in 1947 to 116,000 in $1950 .{ }^{106}$ Even in Mississippi, where resistance to black suffrage remained intense, black voter registration rose from 2,500 in 1946 to 20,000 in $1950 .{ }^{107}$

Based on this stunning increase in Southern black voter registration, the NAACP proclaimed Smith "a giant milestone in the progress of Negro Americans toward full citizenship." 108 Without Smith, these changes probably would not have taken place when they did. ${ }^{109}$ But even with Smith, other supportive conditions were necessary to accomplish this "first real break-through since 1900 in the rights of the Negro people to exercise the franchise." ${ }^{110}$ One important change that had taken place between Grovey in 1935 and Smith in 1944 was the greater receptivity of Southern whites to black political participation. One should not overstate the point; many whites, especially in the Deep South, remained bitterly opposed to black suffrage with its historical connotations of "Negro domination." Yet by 1944, that reactionary perspective faced new competition. Many Southern white newspapers, especially but not exclusively in the peripheral South, endorsed Smith on the ground that blacks should receive "their fair and just political . . . rights." ${ }^{111}$ An editorial appearing in the white

102. For the 1948 estimate, see $i d$. at fr. 549 . For the 1952 estimate from the Southern Regional Council, see Numan V. BARTley, The New South, 1945-80: The Story of The SOUTH's MODERNIZATION 171 (1995).

103. HINE, supra note 10, at 238; LAWSON, supra note 10, at 134 tbl.1.

104. Along the N.A.A.C.P. Battlefront, 55 THE CRISIS 274, 274 (Sept. 1948).

105. Adam Fairclough, Race \& Democracy: The Civil Rights Struggle in LOUISIANA, 1915-1972, at 106, 131 (1995); Weber, Citizenship, supra note 101, at fr. 550.

106. Steven F. Lawson, David R. Colburn \& Darryl Paulson, Groveland: Florida's Little Scottsboro, 65 FLA. HisT. Q. 1, 2 (1986); see also Caroline Emmons, "Somebody Has Got To Do That Work:" Harry T. Moore and the Struggle for African-American Voting Rights in Florida, 82 J. NEGRo HIST. 232, 242 (1997) (noting that between 1948 and 1950, more blacks registered to vote than at any other time in Florida history, as the percentage of eligible blacks registered rose from 16.9 percent to 31.7 percent).

107. LAWSON, supra note 10, at 114 .

108. Editorial, 116,000 Georgia Registrants, 53 THE CRISIS 201, 201 (July 1946).

109. For other scholars and commentators attributing great causal significance to Smith, see FAIRCLOUGH, supra note 105, at 102; HINE, supra note 10, at 222-23; HENRY LeE Moon, Balance of Power: The Negro Vote 178 (1948).

110. Weber, Citizenship, supra note 101, at fr. 549.

111. Time Bomb, Time, Apr. 17, 1944, at 20, 21 (quoting the Dallas News). Other supportive white newspaper reaction is reproduced in Editorial, Time for Statesmanship, 
newspapers of Columbus and Macon, Georgia, which advocated compliance with Smith, elicited surprising statements of support for the author, rather than the anticipated harassing midnight phone calls. ${ }^{112}$ When Deep South states adopted evasive measures after Smith to impede black political participation, many white newspapers voiced opposition. ${ }^{113}$ When Alabamians voted in 1946 on whether to change their constitution to empower registrars to administer vaguely worded literacy tests designed to bar black voter registration-the so-called Boswell amendment-only a bare majority of whites (fifty-four percent) supported the measure. ${ }^{114}$

Some progressive white Southerners, including those supporting organized labor's concurrent efforts to unionize the South, calculated that black enfranchisement probably would benefit liberal politicians. ${ }^{115}$ Economically populist and racially moderate governors, like Earl Long of Louisiana and Big Jim Folsom of Alabama, not only tolerated, but actively supported, the surge in black voter registration that followed Smith. ${ }^{116}$ Folsom campaigned against the Boswell amendment in 1946, and as governor, urged blacks who had been unfairly denied registration to sue local officials who proved beyond the governor's political control. ${ }^{117}$ The white political establishment in Atlanta apparently also endorsed black suffrage, as Fulton County registrars in 1948 not only permitted blacks to register, but actually set up shop in black schools and churches to facilitate their enroll-

51 The Crisis 136 (May 1944); Supreme Court Rules Out White Primaries, 51 The Crisis 164, 165 (May 1944).

112. Report by the Committee of Editors and Writers of the South, Voting Restrictions in the 13 Southern States, microformed on NAACP Papers, pt. IV, reel 7, frs. 451-67.

113. See, e.g., Editorial, White Supremacy, DALLAS NEWS (Jan. 7, 1948), id. pt. IV, reel 8, fr. 211; Editorial, Mississippi Mud, BiRmingham Herald (Aug. 7, 1947), id. pt. IV, reel 9, fr. 126; Editorial, An Expected Decision, ATlanta Const. (Mar. 4, 1946), id. pt. IV, reel 7, fr. 713; see also Popham, supra note 71, at 44 (noting that most of Alabama's large newspapers opposed the Boswell Amendment).

114. V.O. Key, JR., Southern Politics In State AND Nation 635 (1949) (noting that the vote on the Boswell amendment disproves the notion that all white southerners think alike on racial issues); LAWSON, supra note 10, at 91-92.

115. See Weber, Citizenship, supra note 101, at fr. 549.

116. On Folsom, see LAWSOn, supra note 10, at 91; RoberT J. NorRELL, REAPING THE WhiRlwind: The Civil Rights Movement in Tuskegee 72-74, 88-89 (1985); George E. Sims, The LitTle Man's Big Friend: James E. Folsom in Alabama Politics, 1946-1958, at 163-65, 168, 171-72 (1985); Members Deny Conspiracy Against Votes (unidentified and undated press clipping), microformed on NAACP Papers, pt. IV, reel 6, fr. 241; Letter from O.H. Finney, Jr., to Willie Louis Dick (Dec. 6, 1949), id. pt. IV, reel 6, fr. 248. On Long, see FAIRCLOUGH, supra note 105, at 132; Weber, Citizenship, supra note 101, at fr. 550. For other Southern politicians endorsing Smith, or at least declining to evade or defy it, see Ellis ARNAll, The SHORE Dimly SEEN 59-60 (1946) (Governor Arnall of Georgia); Rehearing Sought on Negroes' Voting, N.Y. TIMES, Apr. 5, 1944, at 12 (Governor Coke Stevenson of Texas); Flyer Encouraging Blacks to Register (June 26, 1944), microformed on NAACP Papers, pt. IV, reel 6, fr. 267 (Chauncey Sparks of Alabama); Emmons, supra note 106, at 235 (Florida Attorney General Tom Watson).

117. SIMS, supra note 116, at 163-164. 
ment. ${ }^{118}$ Even in South Carolina, some white Democrats struggled to open their party to blacks, reasoning that a great many black citizens were "now qualified in mind and character to take part in our form of government," 119 that black soldiers were doing their part in a war fought for democratic ends, and that black enfranchisement would help convince minority peoples around the world that American democracy protected human rights without regard to race. ${ }^{120}$

Many ordinary white citizens, lacking in any particular political incentive, tolerated or even supported black suffrage because they could not see how to justify continued disfranchisement in a democratic age. Novel schemes to impede black suffrage were, in the words of one white newspaper, an effort "to turn the clock back, a failure to face up to facts." 121 One white South Carolina Democrat wrote to Thurgood Marshall to distance himself from his party's continuing efforts to exclude blacks, which he believed "profan[ed] the Bill of Rights." ${ }^{22}$ A white Alabama Democrat criticized her party's continued proscription of blacks as a "cruel and a shameful thing." ${ }^{123}$ Other Southern whites shared the view that "[m]en who faced bullets overseas deserve ballots at home" and that black disfranchisement reflected "the [same] hateful ideologies" that the country had been fighting against in World War II. ${ }^{124}$

Another critical change in circumstance that enabled more effective enforcement of Smith was the greater capacity of Southern blacks by 1944 to capitalize on a favorable Court decision. Earlier civil rights victories in the Supreme Court had entailed few practical consequences, partly because the African-American community had been unable to mobilize behind their enforcement. ${ }^{125}$ Smith was a

118. AtLANTA DAily WoRlD (Apr. 13, 1948), microformed on NAACP Papers, pt. IV, reel 8 , fr. 228.

119. NAACP Press Release (May 5, 1942), id. pt. IV, reel 10, fr. 715.

120. Letter from James M. Hinton to Thurgood Marshall (Apr. 22, 1942), id. pt. IV, reel 10, frs. 709-10; Negro Suffrage in Primaries Urged by 21 White Citizens (unidentified and undated press clipping), id. pt. IV, reel 10, fr. 729.

121. Editorial, Mississippi Mud, supra note 113, at fr. 126.

122. Letter from John M. Lofton, Jr., to Thurgood Marshall (undated), microformed on NAACP Papers, pt. IV, reel 9, fr. 957.

123. Letter from Dorothy Q. Rainey to J. Lon Duckworth (June 20, 1944), id. pt. IV, reel 7, frs. 592-93.

124. Political advertisement, Qualified to Vote But Denied the Chance, BIRMINGHAM Post (June 17, 1946), id. pt. IV, reel 6, frs. 263-66. For other examples of white support for black political participation, see Greater Little Rock Ministerial Alliance Opposes S.B. 256 and S.B. 257, ARK. LAB. J. (Feb. 28, 1945), id. pt. IV, reel 6, fr. 692; Letter from B.R. Edmunds to NAACP, supra note 97 , at fr. 424.

125. See, e.g., Klarman, Progressive Era, supra note 7, at 919-21 (noting that the grandfather clause decisions had no impact on black disfranchisement); id. at 926-30 (noting that Bailey v. Alabama, 219 U.S. 219 (1911), and United States v. Reynolds, 235 U.S. 133 (1914), had little impact on Southern black peonage); id. at 941-44 (noting that Buchanan v. Warley, 245 U.S. 60 (1917), had no significant impact on residential segregation). 
highly salient event for Southern blacks, and they quickly seized upon it as the occasion for registering to vote and demanding access to Democratic primaries. ${ }^{126}$ Thousands of returning World War II veterans took their release papers that entitled them to exemption from the poll tax, headed off to city hall, and demanded that they be registered to vote. ${ }^{127}$ Many expressed the conviction that "[a]fter having been overseas fighting for democracy, ... when we got back here we should enjoy a little of it." ${ }^{128}$ Non-veterans also sought to register in large numbers after Smith. ${ }^{129}$ Across the South, blacks established progressive voters' leagues, which conducted voter education classes to enable registrants to pass literacy tests and organized campaigns to encourage blacks to vote. ${ }^{130}$ Record numbers of Southern blacks attempted to vote in Democratic primaries during 1944, notwithstanding public statements by party officials that blacks would remain barred. ${ }^{131}$ Many of those blacks rejected at the polls filed affidavits recording their experiences with the NAACP and the Justice Department. ${ }^{132}$

The proliferation of lawsuits challenging continued exclusion of blacks from Democratic primaries also evidenced the greater assertiveness of Southern blacks during and after World War II. Blacks brought such suits in Georgia in 1944, Florida in 1944-45, and

126. On Smith's salience, see Letter from Fred James to NAACP (Apr. 11, 1944), microformed on NAACP Papers, pt. IV, reel 6, frs. 845-47; Letter from Houston Dutton to NAACP (Aug. 10, 1944), id. pt. IV, reel 8, frs. 396-97; Letter from Benjamin James Pittman to NAACP (July 2, 1946), id. pt. IV, reel 10, frs. 820-23; FAIRCLOUGH, supra note 105 , at 89

127. John DitTmer, Local People: The Struggle for Civil Rights In Mississippi 19 (1994); FAIRCLOUGH, supra note 105, at 111; LAWSON, supra note 10, at 102; NORRELL, supra note 116 , at $60-61$.

128. NORRELL, supra note 116 , at 61.

129. See, e.g., Letter from Legal Redress Committee of the Birmingham Branch of the NAACP to the Chairman of the Jefferson County Board of Registrars (June 29, 1944), microformed on NAACP Papers, pt. IV, reel 6, frs. 76-77 [hereinafter Legal Redress Committee]; Letter from Emory O. Jackson to Legal Redress and Registration Committees (Aug. 18, 1944), id. pt. IV, reel 6, frs. 83-84; unidentified press clipping (Feb. 13, 1945), id. pt. IV, reel 6, fr. 274; Letter from Arthur A. Madison to Thurgood Marshall (May 8, 1944), id. pt. IV, reel 6, frs. 325-26.

130. See, e.g., Flyer Encouraging Blacks to Register, supra note 116, at fr. 267; Statement by the Progressive Voters League of Fla. (June 20, 1945), microformed on NAACP Papers, pt. IV, reel 7, frs. 42-43; Newsletter from NAACP (May 4, 1944), id. pt. IV, reel 7, fr. 414; John H. McCray, The Progressive Democratic Party in South Carolina, S. Frontier (Aug. 1944), id. pt. IV, reel 9, frs. 397-399; Ben Green, Before His Time: The UNTOLD STORY OF HARRY T. MOORE, AMERICA'S FIRST CIVIL RIGHTS MARTYR 54, 59 (1999); LAWSON, supra note 10, at 101-02, 126; SULLIVAN, supra note 69, at 170, 212.

131. See, e.g., Negroes Are Selected for Primary Vote Test, AtLanTa Const. (July 1, 1944), microformed on NAACP Papers, pt. IV, reel 7, fr. 610; Letter from James M. Hinton to Thurgood Marshall, supra note 120, at 709-710; Letter from E.M. Cams (May 15, 1942), microformed on NAACP Papers, pt. IV, reel 10, fr. 721.

132. See, e.g., Mary Moore Affidavit (Feb. 9, 1945), microformed on NAACP Papers, pt. IV, reel 6, fr. 120; Enna Pope Affidavit (Feb. 9, 1945), id. pt. IV, reel 9, fr. 121; Ida Rodgers Affidavit (Feb. 10, 1945), id. pt. IV, reel 9, fr. 122. 
South Carolina in $1947,{ }^{133}$ and threatened many additional suits against recalcitrant party officials who continued to ignore Smith. ${ }^{134}$ Blacks in some Southern locales became so enthusiastic to sue that efforts by the NAACP's national office to coordinate litigation strategy went for naught. Thurgood Marshall and the national legal staff preferred to defer civil damages suits until after the Justice Department had decided whether to bring criminal prosecutions for violations of Smith. ${ }^{135}$ Yet before the national office could communicate its preferences, the branch in Columbus, Georgia, already had proceeded too far down the litigation path to change course. The branch president explained to the NAACP that "the people demanded that we continue the case." ${ }^{136}$ The branch in Jackson, Mississippi, likewise showed reluctance to accede to the national office's preference for postponing civil litigation, because many members "are becoming impatient . . . and we are anxious to try to do something." 137 Six months later, the branch president reminded Marshall that members "are very anxious to go to the courts with the case."138 Blacks seeking to vote in the South Carolina Democratic primary in 1946 similarly were "expecting great things and are looking for a suit." 139

Blacks responded to Smith by initiating another sort of litigation as well. Because Smith (theoretically) had opened Democratic primaries to blacks, their right to vote finally had acquired some practical value in the one-party South. Southern blacks now demanded that they be registered to vote without regard to race and sued registrars who continued to discriminate. By the second half of 1945 , blacks had brought such suits against registrars in Birmingham and Tuskegee, Alabama; Jacksonville and Titusville, Florida; St. John the Baptist

133. See King v. Chapman, 62 F. Supp. 639 (M.D. Ga. 1945), aff'd, 154 F.2d 460 (5th Cir. 1946); White Primary Attacked in Legal Action Here, ATlanta Const. (June 14, 1945), microformed on NAACP Papers, pt. IV, reel 7, fr. 676 (noting Jackson v. Suttles, filed in federal court in Atlanta); Democratic Vote of Negroes Upheld, supra note 71, at 24 (reporting a Florida Supreme Court decision and noting "several" similar suits in various Florida counties).

134. See, e.g., Letter from Daniel E. Byrd to H.J. Levy (Oct. 20, 1947), microformed on NAACP Papers, pt. IV, reel 8, frs. 514-15; Letter from Donald Jones to Thurgood Marshall (Oct. 22, 1947), id. pt. IV, reel 8, fr. 526.

135. See, e.g., Letter from Thurgood Marshall to Arthur D. Shores (May 5, 1944), id. pt. IV, reel 6, fr. 70; Letter from Thurgood Marshall to Edward D. Davis (May 2, 1944), id. pt. IV, reel 6, fr. 851.

136. Letter from W.M. Thomas to Thurgood Marshall (Aug. 28, 1944), id. pt. IV, reel 8, fr. 90 .

137. Letter from J. Wesley Dixon to Thurgood Marshall (Aug. 28, 1944), id. pt. IV, reel 7 , fr. 420 .

138. Letter from Carsie A. Hall to Thurgood Marshall (Feb. 16, 1945), id. pt. IV, reel 9, fr. 8.

139. Letter from Harold R. Boulware to Thurgood Marshall (July 5, 1946), id. pt. IV, reel 10, frs. 825-27; see also Letter from James M. Hinton to Thurgood Marshall (Dec. 21, 1945), id. pt. IV, reel 10, fr. 807. 
Parish, Louisiana; and Atlanta. ${ }^{140}$ Many more blacks besieged registration boards with letters threatening lawsuits if discriminatory registration practices continued. ${ }^{141}$ When the registrar in Lake Charles, Louisiana, denied enrollment to black applicants through a variety of unlawful stratagems, they consulted a lawyer who promptly telephoned the registrar to threaten him with legal action. ${ }^{142}$ Louisiana blacks were "bursting with anxiety to knock out" discriminatory registration practices. ${ }^{143}$

This propensity toward litigation partly was attributable to the greater black militancy spawned by World War II. Yet two other developments traceable mainly to the war also facilitated broader litigation: the spread of NAACP branches into more remote parts of the South and the improved economic status of blacks generally. ${ }^{144}$ NAACP membership grew from roughly 50,000 in 1940 to 450,000 in 1946 , and the number of branches rose from 355 to $1,073 .{ }^{145}$ In one of the region's most racially recalcitrant states, South Carolina, NAACP membership grew from roughly 800 in 1939 to 14,000 in $1948 .{ }^{146}$ More NAACP branches meant that more Southern communities were able to support litigation against defiant public and party officials. NAACP branches communicated valuable information regarding local voting practices to one another, often through the national office or the state conference of branches. ${ }^{147}$ Blacks in one community became more determined to vote after discovering that blacks elsewhere in their state had become enfranchised. Increased NAACP membership also translated into a larger legal budget, which meant that the national office finally could hire several lawyers to supplement Thurgood Marshall's heroic efforts. In the early 1940s, the New York office often had been too swamped to provide much assistance

140. See Hall v. Nagel, 154 F.2d 931 (5th Cir. 1946); Mitchell v. Wright, 154 F.2d 924 (5th Cir. 1946); Along the NAACP Battlefront, 52 THE CRISIS 231 (Aug. 1945); NAACP Files New Vote Registration Case in Alabama (June 21, 1945), microformed on NAACP Papers, pt. IV, reel 6, fr. 151; Letter from Harry T. Moore to Thurgood Marshall (Apr. 23, 1946), id. pt. IV, reel 7, fr. 365; Letter from Thurgood Marshall to Francis J. Biddle (Oct. 3, 1944), id. pt. IV, reel 8, frs. 433-34.

141. See, e.g., Legal Redress Committee, supra note 129, at frs. 76-77; Letter from E.K. McIlrath to Jacksonville City Commissioners (May 3, 1945), microformed on NAACP Papers, pt. IV, reel 7, frs. 22-23; Letter from Daniel E. Byrd to Jackson Parish Registrar of Voters (Oct. 21, 1947), id. pt. IV, reel 8, frs. 518-19.

142. A.P. Tureaud memorandum on Registrars' Practices in Various La. Parishes (Sept. 1, 1944), id. pt. IV, reel 8, frs. 407-10 [hereinafter Tureaud memorandum].

143. Id. at fr. 410.

144. On the spread of NAACP branches, see Editorial, 5 Million Voters by 1950-A Laudable Objective, SHREVEPORT SUN (Apr. 30, 1949), microformed on NAACP Papers, pt. IV, reel 7, fr. 563.

145. Richard M. Dalfiume, Desegregation of the U.S. ARmed Forces: Fighting ON TwO FRONTS, 1939-53, at 123 (1969).

146. BARTLEY, supra note 102, at 29.

147. See, e.g., Letter from William Henry Samuel to NAACP (Sept. 7, 1948), microformed on NAACP Papers, pt. IV, reel 8, fr. 600. 
to Southern branches in litigating voting cases. ${ }^{148}$ After the war, an expanded legal staff was better able to provide advice and actual lawyering in support of the voting rights campaign.

Larger branch memberships and more prosperous members translated into more money available to hire lawyers. The president of the Shreveport branch, seeking advice from the national office about how best to compel registrars to enroll blacks, announced that his branch was "ready with finances for anything." 149 The branch in Jackson, Mississippi, eager to litigate against continuing exclusion of blacks from Democratic primaries, assured the national office of its ability to finance the litigation by itself. ${ }^{150}$ In addition, more Southern white lawyers were now willing to take voting rights cases, given diminishing resistance among whites to black suffrage. ${ }^{151}$ More black lawyers also practiced in the South by the mid-1940s, which proved helpful whenever doubts remained as to the willingness of particular white lawyers to exert themselves sufficiently on behalf of black suffrage. ${ }^{152}$

The threat of litigation challenging the discriminatory administration of voter registration requirements or the exclusion of blacks from Democratic primaries provided public and party officials with a direct incentive to comply with the Constitution. While these officials overwhelmingly preferred that blacks not vote, they did not wish to incur personal liability for violating black voting rights. With threats of litigation flying from all directions, these officials began to comply

148. On Marshall's overextension in the early 1940s and how this interfered with voting rights activity in the South, see Letter from Norman Lacey to Walter White (May 26, 1940), id. pt. IV, reel 7, frs. 121-25 (pleading with the NAACP to "do something tangible" and noting that "it is very necessary that the ass[ociatio]n does something in Tampa for we are on the spot"); Letter from D.H. Malloy to the NAACP (Nov. 22, 1941), id. pt. IV, reel 7, frs. 177-78 (complaining that the Tampa branch has kept the national office informed of its local white primary case, but its communications have been consistently ignored); Letter from Frank D. Reeves to E. Norman Lacey (Nov. 26, 1941), id. pt. IV, reel 7, fr. 176 (apologizing to Lacey for the national office's failure to respond promptly to his previous letters and explaining that the national office has only a small staff and that Thurgood Marshall frequently is out of the office in connection with various NAACP obligations); Letter from J.L. Leflore to Walter White (Nov. 29, 1941), id. pt. IV, reel 7, frs. 179-82 (reiterating the complaints of the Tampa Branch).

149. Letter from Donald Jones to Thurgood Marshall (Dec. 10, 1947), id. pt. IV, reel 8, fr. 544 (reporting statement of branch president Williams).

150. Letter from Carsie A. Hall to Thurgood Marshall, supra note 138, at fr. 8.

151. See, e.g., Letter from Houston Dutton to Thurgood Marshall (Sept. 28, 1944), microformed on NAACP Papers, pt. IV, reel 8, frs. 418-19. For the difficulty in securing white lawyers at an earlier date, see Letter from McPherson to NAACP (Nov. 9, 1920), id. pt. IV, reel 1, frs. 445-46 (noting the branch's "inability to secure the services of the white lawyers to look after our interest," which suggests "a mutual understanding of some kind" between those lawyers and the public officials resisting black voter registration).

152. On new black lawyers, see Letter from Carsie A. Hall to Thurgood Marshall (Aug. 27, 1945), id. pt. IV, reel 9, fr. 13; FAIRCLOUGH, supra note 105, at 134. For suspicion of white lawyers, see Letter from Carsie A. Hall to Thurgood Marshall, supra; Letter from Louis Thompson to Thurgood Marshall (Dec. 23, 1944), microformed on NAACP Papers, pt. IV, reel 9, fr. 257. 
with the law. In Spalding County, Georgia, local officials had little choice but to register black voters without discrimination, after Federal Judge Frank Scarlett ordered them to do so and then held the case open pending further complaint. ${ }^{153}$ Local registration officials in several South Carolina counties, fearing federal court litigation, defied orders from the state Democratic Party by registering black voters. ${ }^{154}$ After Judge Waring in 1947 and 1948 invalidated efforts by the South Carolina Democratic Party to evade Smith and threatened to hold party officials in contempt, 35,000 blacks were enrolled on party membership books. ${ }^{155}$ In Washington Parish, Louisiana, blacks had been denied registration until they formed an NAACP branch and filed suit before a sympathetic federal judge, J. Skelly Wright, who enjoined the registrar from further race discrimination. ${ }^{156}$ As a result of this litigation, Washington Parish registered its first black voter in 1950. That precedent inspired federal lawsuits in several other Louisiana parishes, which induced registrars to enroll blacks rather than risk personal liability. ${ }^{157}$

By the mid-1940s, damages suits were not all that recalcitrant officials had to fear; criminal prosecution by the Federal Government now became a distinct possibility. Southern NAACP branch officials constantly reminded public and party officers that willful violations of black voting rights qualified for federal prosecution under civil rights statutes. ${ }^{158}$ Indeed, the Justice Department already had prosecuted a few registrars for discriminatory practices-one in North Carolina in the mid-1930s and two others in the Carolinas in the early 1940s. ${ }^{159}$ One important consequence of burgeoning black

153. Judge Orders Spalding to List Negroes, AtlantA Const. (Aug. 20, 1948), microformed on NAACP Papers, pt. IV, reel 6, fr. 218.

154. Letter from Harold R. Boulware to Thurgood Marshall, supra note 139, at fr. 825; Harold R. Boulware memorandum on Problem Presented by South Carolina: Brown v. Baskin (June 21, 1949), microformed on NAACP Papers, pt. IV, reel 9, frs. 476, 481 [hereinafter Boulware memorandum].

155. Along the N.A.A.C.P. Battlefront, supra note 104

156. FAIRCLOUGH, supra note 105, at 133-34; Dean v. Thomas, 93 F. Supp. 129 (E.D. La. 1950).

157. See, e.g., Byrd v. Brice, 104 F. Supp. 442 (W.D. La. 1952). See also Letter from Joseph A. Berry \& Daniel L. Beasley to Walter White (July 20, 1948), microformed on NAACP Papers, pt. IV, reel 6, frs. 208-14; Letter from Charles A. Chandler to Charles H. Houston (Apr. 8, 1937), id. pt. IV, reel 3, fr. 203 (Muskogee County, Okla.). Marshall urged branches to bring more lawsuits. See, e.g., Letter from Thurgood Marshall to Arthur D. Shores (Apr. 18, 1945), id. pt. IV, reel 6, fr. 136.

158. See, e.g., Letter from Daniel E. Byrd to H.J. Levy, supra note 134, at frs. 514-15; Letter from Chair of Alexandria, La., Branch Legal Committee to NAACP (Sept. 30, 1944), microformed on NAACP Papers, pt. IV, reel 8, fr. 424; Letter from G.M. Johnson to Nora Windon (Aug. 1948), id. pt. IV, reel 8, frs. 592-93.

159. For the successful North Carolina prosecution in 1936, see Letter from Thurgood Marshall to Tom Clark (Sept. 11, 1944), microformed on NAACP Papers, pt. IV, reel 9, frs. 236-37. For the unsuccessful North Carolina prosecution in 1942, see Letter from Thurgood Marshall to W. R. Saxon (May 14, 1942), id. pt. IV, reel 9, fr. 180. For the unsuccess- 
political power was that Justice Department officials became more solicitous of the voting rights of Southern blacks. The Department repeatedly invited Thurgood Marshall to Washington, D.C., to discuss voting issues, and assured Southern NAACP officials that their voting rights complaints were receiving thorough investigation. ${ }^{160} \mathrm{By}$ way of contrast, the Justice Department in the mid-1930s generally had manifested indifference toward the voting rights protests of Southern blacks. Back then, United States attorneys merely went through the motions of investigating complaints and were as likely to intimidate black victims as to prosecute their cases. ${ }^{161}$

Immediately after Smith, Thurgood Marshall wrote to Attorney General Francis Biddle, requesting that the government instruct United States attorneys to prosecute party officials who continued to exclude blacks from primary elections. ${ }^{122}$ NAACP lawyers bombarded Justice Department officials with affidavits from Southern blacks attesting to persistent violations of black voting rights and demands for criminal prosecutions. ${ }^{163}$ One NAACP officer in Birmingham, Alabama, bragged that he was sending "a bag of evidence almost daily" to the Justice Department. ${ }^{164}$ By the fall of 1944, Marshall was in regular conference with Department lawyers, including the Attorney General, negotiating over when and where the government would

ful South Carolina prosecution, see Three Men Charged with Civil Rights Violations, Greenville News (S.C.) (Nov. 27, 1941), id. pt. IV, reel 10, fr. 633; Letter from Lottie P. Gaffney to Thurgood Marshall (Feb. 28, 1942), id. pt. IV, reel 10, frs. 644-45.

160. See, e.g., Letter from Francis J. Biddle to Thurgood Marshall (Aug. 8, 1944), id. pt. IV, reel 7, fr. 418; Letter from Francis J. Biddle to C.A. Scott (Dec. 1, 1944), id. pt. IV, reel 10, frs. 628-29; Letter from Thurgood Marshall to Tom Clark (May 9, 1944), id. pt. IV, reel 6, fr. 327 .

161. See, e.g., Letter from Walter White to Homer S. Cummings (Aug. 30, 1935), id. pt. IV, reel 2, frs. 220-21 (calling the Department's investigation of NAACP allegations of discriminatory voter registration in Wilkesboro, North Carolina, "a flagrant whitewash" and noting that the one federal agent who did interview complainants "intimidate[d] and threaten[ed]" them); Letter from Charles H. Houston to the U.S. Attorney General (Oct. 16, 1935), id. pt. IV, reel 2, frs. 231-32 (calling the Department's performance with regard to these allegations of discriminatory voter registration in North Carolina "a sad commentary" and asking whether the Department is "an adjunct of the Democratic [P]arty"); Letter from Charles H. Houston to the U.S. Attorney General (Nov. 18, 1935), id. pt. IV, reel 2, fr. 259 (asking the Department to appoint a Special Prosecutor because the U.S. attorney in North Carolina refused "to make any real, serious, honest attempt to investigate" allegations of discriminatory voter registration); see also Letter from John Marshall to Robert W. Bagnall (Oct. 23, 1928), id. pt. IV, reel 2, fr. 347 (noting that "[o]fficials refusing to register eligible voters may be punished under State laws" and emphasizing the "limited" scope of federal election laws) (emphasis added).

162. See Supreme Court Rules Out White Primaries, supra note 111, at 164-65; Time Bomb, supra note 111, at 20-21; LAWsON, supra note 10, at 47.

163. See, e.g., Letter from Milton R. Konvitz to Victor Rotnem (Apr. 17, 1944), microformed on NAACP Papers, pt. IV, reel 6, fr. 309; Letter from Thurgood Marshall to Francis J. Biddle (July 5, 1944), id. pt. IV, reel 8, frs. 133-34; Letter from Thurgood Marshall to Francis J. Biddle (July 19, 1944), id. pt. IV, reel 8, frs. 138-40.

164. Letter from Emory O. Jackson to Thurgood Marshall (Feb. 16, 1945), id. pt. IV, reel 6 , fr. 131 . 
commence prosecutions. ${ }^{165}$ In early 1945, the New York Times reported that Department officials were contemplating immediate prosecutions in three Southern states. ${ }^{166}$ A year later, the Department issued a policy statement declaring that it would prosecute any public or party official attempting to interfere with black voting rights. ${ }^{167}$

Notwithstanding its bold pronouncements, the Justice Department remained reluctant to prosecute voting rights cases. However, it did launch investigations and dispatch FBI agents to Southern communities to gather information, thus offering food for thought to Southern officials contemplating interference with black voting rights. Birmingham lawyer Arthur Shores reported to Marshall that a personal visit from the United States Attorney to the local board of registrars "had a very wholesome effect on helping us get . . . a large number [of black voters] registered." 168 Harry Moore, founder of the Florida Progressive Voters' League, believed that a federal investigation of the incident in Greensboro, Florida, in which two black brothers were attacked and then run out of town in retaliation for their voter registration activities would have "a healthy effect in all of those counties, where Negroes have been kept from the polls through intimidation." 169 One of these brothers later reported that the FBI's appearance in Greensboro had the "crack[er]s . . . looking very sick ...." Moreover, a heightened federal law enforcement presence in the South, even if it did not result in actual prosecutions, provided some modicum of security to Southern blacks who risked their physical safety by challenging the political status quo. Donald Jones, Southwest Regional Secretary of the NAACP, warned the chairman of the Caddo Parish (Louisiana) Democratic Executive Committee that he risked criminal prosecution for supporting the continued exclusion of blacks from party primaries. Jones then quickly reminded Thurgood Marshall to mention this case to the Justice Department, because "I threatened the gentleman and don't want to be caught with my breeches at half mast." 171

165. See, e.g., Letter from Thurgood Marshall to C.A. Scott (Oct. 27, 1944), id. pt. IV, reel 8, fr. 104; Letter from Thurgood Marshall to John L. LeFlore (Nov. 23, 1945), id. pt. IV, reel 6, fr. 548 .

166. Arnall to See Biddle on Negro Franchise, N.Y. TIMES (Mar. 14, 1945), id. pt. IV, reel 8 , fr. 141 .

167. Justice Dept. to Follow Ruling in Election Case, Charleston Evening Post (S.C.) (Apr. 6, 1946), id. pt. IV, reel 7, fr. 430.

168. Letter from Arthur Shores to Thurgood Marshall (Sept. 16, 1939), id. pt. IV, reel 3, fr. 182 .

169. Letter from Harry T. Moore to Thurgood Marshall (July 12, 1948), id. pt. IV, reel 6, fr. 791.

170. Letter from J.T. Smith to NAACP (Aug. 20, 1948), id. pt. IV, reel 6, fr. 798.

171. Letter from Donald Jones to Thurgood Marshall (Oct. 22, 1947), id. pt. IV, reel 8, fr. 526; see also Letter from Thurgood Marshall to S.M. Coleman (June 29, 1950), id. pt. IV, 
Even apart from the greater presence of the Federal Government, the South was a safer place for blacks by the mid-1940s than it had been even a decade earlier-a change in circumstance that surely contributed to the greater aggressiveness with which blacks demanded their constitutional rights. It is important, however, not to overstate the point. Southern whites lynched blacks with somewhat greater frequency during and after the War than immediately before, ${ }^{172}$ and Thurgood Marshall himself barely escaped with his life while defending criminal cases arising from the Columbia, Tennessee, race riot in $1946 .{ }^{173}$ Yet the South had become a relatively safer place for blacks, owing to the same forces that were gradually eradicating lynchings - urbanization, industrialization, better education, less insularity, and the threat of federal anti-lynching legislation and criminal prosecution for civil rights violations. ${ }^{174}$ The greater physical security enjoyed by Southern blacks was vitally important to the voting rights campaign launched after Smith, as well as to the direct action protests of the early 1960s.

Some quick comparisons between interwar and postwar Southern social conditions illustrates this point. In Jacksonville, Florida, a $\mathrm{Ku}$ Klux Klan (KKK) demonstration on election eve, 1920, drew a thousand participants and deterred nearly all blacks in the city from voting. ${ }^{175}$ That same year, as many as fifty blacks died in election riots in Ocoee, Florida. ${ }^{176}$ Fearing for their safety, black witnesses to the riot declined to testify before an investigating committee in Washington, D.C. In 1932, police officers in Shreveport, Louisiana, armed with machine guns, suppressed an effort by local blacks to organize a voters league. City authorities warned that the streets would be drenched with blood before they would permit blacks to vote, and a

reel 8, fr. 613 (noting that Marshall had brought to the attention of the Justice Department the registration difficulties of blacks in Benton, Louisiana).

172. See Robert L. Zangrando, The NAACP Crusade Against Lynching, 1909 1950 , at 6-7 tbl.2 (1980).

173. TUSHNET, supra note 91, at 54-55. On the Columbia race riot, see GAIL WILLIAMS O’Brien, The Color of the LaW: Race, Violence, and Justice in the Post-World War II SOUTH (1999).

174. For various explanations for the decline in the number of lynchings, see, for example, W. Fitzhugh Brundage, Lynching in the New South: Georgia AND Virginia, 1880-1930, at 209, 238 (1993); MYrdal, supra note 65, at 565; GEORGE B. Tindall, ThE EMERGENCE OF THE NEW SOUTH 1913-1945, at 174, 554 (1967); Kathleen Atkinson Miller, The Ladies and the Lynchers: A Look at the Association of Southern Women for the Prevention of Lynching, 17 S. STUD. 221, 236-37 (1978); Todd E. Lewis, Mob Justice in the "American Congo": "Judge Lynch" in Arkansas During the Decade after World War I, 52 ARK. HIST. Q. 156 (1993).

175. Letter from James Floyd to Walter White (Dec. 7, 1920), microformed on NAACP Papers, pt. IV, reel 1, fr. 936; Letter from Alexander Ackerman to Sen. William C. Kenyon (Nov. 5, 1920), id. pt. IV, reel 1, frs. 925-27.

176. Letter from Alexander Ackerman to Sen. William C. Kenyon, supra note 175, at frs. 925-27. For a recent account of the Ocoee race riot, see Michael McLeod \& Joy Wallace Dickinson, Ocoee Race Riot Scars Generations, ORLAndo SENT., Feb. 5, 2001, at A1. 
black newspaper editor who had helped organize the campaign was forced to leave town under threat to his life. ${ }^{177}$ Similarly, a black man who challenged Mississippi's white primary in 1927 had his life threatened and then was run out of town. ${ }^{178}$ Whites lynched an average of just under fifty Southern blacks annually in the first half of the 1920s and just under twenty in the first half of the 1930s. ${ }^{179}$

Much had changed by the mid-1940s. The KKK was in a weaker position from which to intimidate black voters because it was busy defending itself from state efforts to revoke its charter and federal efforts to prosecute its leaders for tax evasion. ${ }^{180}$ Hundreds of blacks flocked to the Senate committee hearings investigating Senator Theodore Bilbo's incitement of whites to violence against blacks in Mississippi's 1946 senatorial primary-hearings that were held not in the relative safety of Washington, D.C., but in Jackson, Mississippi. ${ }^{181}$ In postwar Louisiana, tens of thousands of blacks registered to vote, even in some rural parishes, with the active support of Governor Long and under the protective eye of the federal courts and the Justice Department. ${ }^{182}$ In the mid-1940s, blacks across the Deep South filed lawsuits challenging denials of voting rights without encountering significant threats of physical violence, although they continued to suffer economic retaliation. ${ }^{183}$ While the annual number of Southern lynchings had increased briefly during the immediate postwar years, it quickly declined again to near zero by the late 1940s. ${ }^{184}$ The Federal Government aggressively investigated and prosecuted the few lynchings that did occur during and after the War. ${ }^{185}$ Blacks attempting to vote in the rural Deep South in the mid1940s were still likely to face physical intimidation, but far more often in the form of a beating than a lynching. ${ }^{186}$ Of course, one does

177. Albert White, Shreveport Peace Officers Dare Negro Democrats to Hold Meeting, Display Machine Guns and Rifles, HOUSTON DEFENDER (July 23, 1932), microformed on NAACP Papers, pt. IV, reel 4, fr. 114.

178. Letter from Mack Holiman to NAACP (Dec. 3, 1927), id. pt. IV, reel 2, frs. 103-04; Letter from James Weldon Johnson to Nathaniel B. Bond (Dec. 30, 1927), id. pt. IV, reel 2, fr. 111; Letter from S.R. Redmond to James Weldon Johnson (Jan. 5, 1928), id. pt. IV, reel 2 , fr. 118 .

179. ZANGRANDO, supra note 172 , at 6-7 tbl.2

180. See, e.g., Georgia on the Move, N.Y. Post (June 3, 1946) microformed on NAACP Papers, pt. IV, reel 8, fr. 175; see also John N. Popham, Dual Racial Stand Voted in Georgia, N.Y. TIMES, Feb. 18, 1951, at 48 (noting that the Georgia legislature, dominated by white supremacists, had adopted by a near-unanimous vote one of the strongest anti-KKK statutes in the South's history).

181. On Bilbo, see infra notes 249-54 and accompanying text.

182. See supra note 105 and accompanying text.

183. See supra notes 133-34 \& 140-41 and accompanying text.

184. ZANGRANDO, supra note 172 , at 6-7 tbl.2.

185. See, e.g., DOMINIC J. CAPECI, JR., The LyNChing OF Cleo Wright ch. 3 (1998).

186. For a black World War II veteran who was beaten for trying to vote, when the mob thought better of killing him, see LAWSON, supra note 10, at 107-08. 
not want to minimize this threat of physical violence. The postwar Deep South remained a dangerous place for blacks intent on exercising their constitutional rights, but the degree of danger had subsided somewhat, thereby enabling Southern blacks to demand their rights without ordinarily putting their lives on the line. ${ }^{187}$

Another important factor contributing to the momentous Southern black voter registration of the 1940s was the willingness of lower court judges to embrace generous interpretations of Smith and the Fifteenth Amendment. Again, the contrast with the 1930s is revealing. Black lawyers arguing the Texas white primary cases before the Fifth Circuit in the early 1930s faced "insult[ing]" judges who literally turned their backs on the lawyers during oral argument. ${ }^{188}$ In correspondence with the NAACP national office, these lawyers repeatedly doubted whether "Southern Judge[s]" ever would vindicate the voting rights claims of black litigants and wondered whether it was worth even bothering to show up for oral argument in the Fifth Circuit, since only a Supreme Court appeal held any promise of success. ${ }^{189}$

The voting rights decisions of Southern judges in the 1930s confirmed these doubts. Judges strained to find technicalities upon which to reject voting rights claims and manifested a willful blindness to the racially discriminatory administration of facially neutral voter qualifications. ${ }^{190}$ Postwar judges, by way of contrast, often proved more accommodating to blacks litigating voting rights issues. This conversion among lower court judges proved crucial to the success of Southern black voter registration because public and party officials contrived a multitude of evasive techniques to impede black suffrage after Smith. Repeated appeals to the Supreme Court were expensive, and the Justices lacked the resources to hear every case alleging evasion of earlier decisions. Thus the receptivity of lower court judges was critical to the effective implementation of Smith.

As noted earlier, many Southern whites, with varying degrees of enthusiasm, were prepared to accept black suffrage by the mid1940s. ${ }^{191}$ Yet most Southern politicians and the public officers they

187. For an example of the greater physical security with which the NAACP operated in rural Louisiana by the 1940s, see FAIRCLOUGH, supra note 105, at 113.

188. Letter from Fred C. Knollenberg \& Frank Cameron to NAACP (Nov. 17, 1930), microformed on NAACP Papers, pt. IV, reel 3, fr. 549.

189. Letter from Fred C. Knollenberg \& Frank Cameron to Arthur B. Spingarn (Sept. 2, 1930), id. pt. IV, reel 3, frs. 527-28 (quotation); Letter from Fred C. Knollenberg \& Frank Cameron to Nathan R. Margold (Nov. 13, 1930), id. pt. IV, reel 3, frs. 550-51; Letter from Arthur B. Spingarn to Walter White (Jan. 28, 1930), id. pt. IV, reel 3, fr. 452.

190. See, e.g., Lane v. Wilson, 98 F.2d 980 (10th Cir. 1938), rev'd, 307 U.S. 268 (1939); Trudeau v. Barnes, 65 F.2d 563 (5th Cir. 1933); Nixon v. Condon, 49 F.2d 1012 (5th Cir. 1931), rev'd, 286 U.S. 73 (1932).

191. See supra notes $111-24$ and accompanying text. 
appointed were not. This is probably no great surprise. Politicians generally are unenthusiasiastic about electoral change, given their vested interest in preserving the system that elected them to office. ${ }^{192}$ Whatever their motives, however, Democratic politicians, party officials, and voter registrars throughout much of the South responded to Smith with defiance and evasion as they endeavored to prevent the Court from "revolutioniz[ing] our Southern customs and disrupt[ing] our peaceable existence." ${ }^{193}$

In most Southern states, the Democratic Party continued to exclude blacks from primaries for at least a year or two after Smith. ${ }^{194}$ Sometimes, they embraced this position with open defiance. ${ }^{195}$ The chairman of the Mississippi Democratic Party Executive Committee, for example, declared that "the Supreme Court or no one else can control a Democratic primary in Mississippi." ${ }^{196}$ In other states, however, party officials rightly noted that Smith did not necessarily invalidate all white primaries. ${ }^{197}$ The Court's ruling partially relied on how Texas law regulated parties and their primaries; other states regulated parties and primaries differently. For example, while Texas law required parties to conduct primaries, Georgia law did not. Even more importantly, to the extent that Smith had turned on the fact of state regulation of political parties, it might be possible to avoid the decision entirely by repealing all statutes regulating parties. South Carolina did exactly this after Smith, and other states contemplated following suit, waiting to see how lower courts evaluated the constitutionality of South Carolina's efforts. ${ }^{198}$

Lower courts generally refused to countenance such evasions. The Fifth Circuit affirmed a district court ruling rejecting proffered distinctions between Georgia's white primary and the Texas variant in-

192. For general discussion of this sort of entrenchment problem and the powerful argument for activist judicial review to counteract it, see Michael J. Klarman, Majoritarian Judicial Review: The Entrenchment Problem, 85 GEO. L.J. 491 (1997); Samuel Issacharoff \& Richard H. Pildes, Politics As Markets: Partisan Lockups of the Democratic Process, 50 STAN. L. REV. 643 (1998).

193. Editorial, 10 ALA. 1 (July 6, 1945), microformed on NAACP Papers, pt. IV, reel 6 , fr. 155.

194. See infra notes $214-17$ and accompanying text.

195. See, e.g., Lewis Wood, High Court Rules Negroes Can Vote in Texas Primary, N.Y. TimES, Apr. 4, 1944, at 1 (quoting defiant statements by several Southern Congressmen); see infra notes 228-34 and accompanying text.

196. Negroes Not Eligible for Primary, Duckworth Says (unidentified press clipping) (Apr. 4, 1944), microformed on NAACP Papers, pt. IV, reel 7, fr. 583.

197. For claims that Smith was distinguishable, see, for example, Georgians 'Reaffirm' 'White Supremacy,' N.Y. TIMES, June 8, 1944, at 38 (quoting resolution of subcommittee of Georgia Democratic State Executive Committee); see also Robert E. Cushman, The Texas "White Primary" Case-Smith v. Allwright, 30 CoRNELL L.Q. 66, 75 (1944) (noting that the laws of Southern states governing primary elections vary and predicting that other cases will have to be appealed to the Supreme Court before the white primary is interred).

198. See supra notes 69-71 and accompanying text. 
validated in Smith. ${ }^{199}$ The Florida Supreme Court ruled similarly. ${ }^{200}$ Perhaps more significantly, Judge Waring sternly repudiated South Carolina's effort to evade Smith by repealing all legal regulation of the Democratic Party, and the Fourth Circuit affirmed him. ${ }^{201}$ These decisions involved more than simple applications of Smith; they required extensions. The Fifth Circuit, for example, explicitly noted that Smith and Classic were not dispositive of the constitutionality of Georgia's white primary because of relevant differences in the ways that Texas and Louisiana had regulated political parties. Yet that court nonetheless concluded that the Georgia Democratic Party's exclusion of blacks violated the Constitution. Lower court judges more antagonistic toward black voting rights could have found ways to resolve these cases differently. Judge Waring, however, decided that "[i]t is time for South Carolina to rejoin the Union." ${ }^{02}$ When party officials responded to Waring's ruling by adopting a dual membership status based on race and a party loyalty oath designed to offend most prospective black members (including a requirement of swearing support for segregation), an enraged Waring enjoined these evasive efforts, and the Fourth Circuit again affirmed him. ${ }^{203}$

Some Southern states in the late 1940s adopted measures to obstruct black voter registration. With Democratic primaries now (theoretically) open to blacks, tougher registration procedures and requirements became a favored alternative method for impeding black suffrage. For example, Alabama voters enacted the Boswell amendment, requiring that registrants "understand and explain" a section of the United States Constitution, not just read it, and also understand "the duties and obligations of good citizenship." ${ }^{04}$ Proponents of the amendment did not disguise their intention to confer broad discretion on registrars for the purpose of preserving white political supremacy. Georgia likewise adopted a tougher voter registration requirement after Smith, though the state tried to avoid the le-

199. King v. Chapman, 62 F. Supp. 639 (M.D. Ga. 1945), aff'd, 154 F.2d 460 (5th Cir. 1946).

200. Davis v. Florida ex rel. Cromwell, 23 So. $2 d 85$ (Fla. 1945).

201. Elmore v. Rice, 72 F. Supp. 516 (E.D.S.C. 1947), aff'd, 165 F.2d 387 (4th Cir. 1947).

202. Id. at 528

203. Brown v. Baskin, 78 F. Supp. 933 (E.D.S.C. 1948), aff'd, 174 F.2d 391 (4th Cir. 1949). Mississippi also adopted such a loyalty oath. See Letter from T.B. Wilson to Walter White (July 14, 1947), microformed on NAACP Papers, pt. IV, reel 9, fr. 117; KEY, supra note 114, at 640-41; Earl M. Lewis, The Negro Voter in Mississippi, 26 J. NEGRO EDUC. 329, 341 (1957).

204. Editorial, supra note 193, at fr. 155; Anti-Poll Tax Solons Soften (unidentified and undated press clipping), microformed on NAACP Papers, pt. IV, reel 6, fr. 280; Mary Ellen Crane, Committee is Formed to Back Amendment 4 (unidentified and undated press clipping), id. pt. IV, reel 6, fr. 281; KEY, supra note 114, at 632-33 (quotations); LAWSON, supra note 10 , at $90-93$. 
gal pitfalls of the Boswell amendment by somewhat constraining the discretion delegated to registrars. ${ }^{205}$

With or without statutory authorization, Southern voter registrars employed a wide variety of stratagems for impeding black suffrage. ${ }^{206}$ Sometimes, registration boards simply closed to prevent blacks from registering. Other times, registrars enrolled voters at undisclosed times in secret locations (contrary to statutory requirements). White registrants discovered through word of mouth where and when to show up, while blacks were kept in the dark. When blacks did locate registrars, they often were forced to wait in line for hours, so that only a few at a time could enroll. Registrars required blacks to complete their own registration forms and then flunked them for trivial errors, while registrars themselves filled out the forms for whites. Registrars asked blacks, but not whites, to recite from memory the entire United States Constitution or to answer impossible (and obviously insulting) questions, such as "how many bubbles are in a bar of soap?" Registrars required blacks, but not whites, to produce already registered voters-and sometimes only whites would suffice-to vouch for information on their application forms. Some registrars did not bother even to indulge in any pretense of legality; they simply told blacks that they would not be registered regardless of their qualifications. Individual registrars often acted as a law unto themselves, ignoring even specific instructions from state officials to treat black registrants fairly. ${ }^{207}$ Thus, registration practices often varied dramatically between different parts of a state or even a city.

For the first time in Southern history, lower courts began ruling such behavior unconstitutional. A three-judge district court consist-

205. See Letter from Thurgood Marshall to Col. A.T. Walden (Mar. 17, 1949), microformed on NAACP Papers, pt. IV, reel 8, fr. 240; Letter from Thurgood Marshall to James M. Nabrit (Apr. 13, 1949), id. pt. IV, reel 8, fr. 241. The Georgia law was sustained by the state supreme court in Franklin v. Harper, 205 Ga. 79 (1949).

206. For examples of the various ruses described in this paragraph, see LAWsON, supra note 10, at 86-115; NORRELL, supra note 116, at 36-40, 44-46, 59-78; Negro Disenfranchisement, supra note 68, at 90-97; Report of the Legislative Committee of the Tuskegee Branch of the NAACP (July 20,1948), microformed on NAACP Papers, pt. IV, reel 6, frs. 208-14; Letter from Joseph A. Berry to Roy Wilkins and Thurgood Marshall (Dec. 10, 1948), id. pt. IV, reel 8, frs. 357-65; Tureaud memorandum, supra note 142, at frs. 407-09; Along the N.A.A.C.P. Battlefront, 59 THE CRISIS 378 (June-July 1952). For some specific examples, see Letter from E.D. Nixon to Walter White (Aug. 11, 1943), microformed on NAACP Papers, pt. IV, reel 6, fr. 42; Affidavit of a group of veterans (June 25, 1946), id. pt. IV, reel 9, fr. 37; Letter from Group denied registration in Rutherfordton, North Carolina, to Walter White (Oct. 31, 1944), id. pt. IV, reel 9, fr. 247; McCray, supra note 130, at fr. 397; Boulware memorandum, supra note 154, at fr. 481.

207. See, e.g., Letter from Harry T. Moore to Thurgood Marshall (Dec. 15, 1945), microformed on NAACP Papers, pt. IV, reel 6, fr. 993; Letter from Harry T. Moore to Thurgood Marshall (May 30, 1946), id. pt. IV, reel 6, fr. 1007; Letter from Emory O. Jackson to Thurgood Marshall (Dec. 13, 1949), id. pt. IV, reel 6, frs. 253-54. 
ing entirely of Southerners invalidated the Boswell amendment on the ground that it delegated to registrars unconstitutionally broad discretion, which had been administered in a racially discriminatory fashion. ${ }^{208}$ The court also noted the obviously discriminatory purpose that had animated the amendment. ${ }^{209}$ The court's refusal to countenance a broad delegation, as well as its willingness to investigate legislative motive, were in tension with the Supreme Court's earlier, more lenient approach toward black disfranchisement. ${ }^{210}$ Other Southern judges likewise began to enjoin registrars from applying voter registration requirements and procedures in racially discriminatory ways. $^{211}$ These courts suspended their customary presumptions that public officials had discharged their legal duties in good faith. When registrars in approximately thirty Georgia counties began purging black voters from the books at the behest of former Governor Eugene Talmadge, a federal judge quickly enjoined them from doing so. ${ }^{212}$ On a somewhat different issue, the Arkansas Supreme Court invalidated a state law designed to meet the challenge of Smith by separating state and federal elections (both primary and general), barring race discrimination only in the federal ones, and therefore implicitly allowing continued exclusion of blacks from state primaries. ${ }^{213}$

The willingness of lower court judges to follow the spirit rather than the letter of Smith and to interpret the Fifteenth Amendment to bar discriminatory voter registration practices that had been tolerated for decades was a necessary condition for the postwar surge in Southern black voter registration. Democratic officials in Georgia and Florida did not allow blacks to participate in primary elections

208. Davis v. Schnell, 81 F. Supp. 872, 877-78 (S.D. Ala. 1949), aff'd, 336 U.S. 933 (1949).

209. Id. at 879-80.

210. Giles v. Harris, 189 U.S. 475 (1903); Williams v. Mississippi, 170 U.S. 213 (1898). For discussion of these cases, see Klarman, Plessy, supra note 15, at 361-66; see also Richard H. Pildes, Democracy, Anti-Democracy, and the Canon, 17 Const. Comm. 295 (2000). For the tension between Davis and Williams, see Negro Disenfranchisement, supra note 68, at 95; see also Francis W. Collopy, Comment, 24 NOTRE DAME LAW. 571, 573 (1949) (noting that Davis is inconsistent with the "strict formalism" of earlier decisions).

211. See, e.g., Byrd v. Brice, 104 F. Supp. 442 (W.D. La. 1952); Dean v. Thomas, 93 F. Supp. 129 (E.D. La. 1950); Mitchell v. Wright, 154 F.2d 924 (5th Cir. 1946), cert. denied, 329 U.S. 733 (1946); Patterson v. Bethea, noted in Letter from Thurgood Marshall to Francis J. Biddle (Oct. 3, 1944), microformed on NAACP Papers, pt. IV, reel 8, frs. 433-34; Florida ex rel. Graham v. Bowden, No. 16237-L (Fla. Cir. Ct. 1945), id. pt. IV, reel 7, frs. 1314.

212. See LAWSON, supra note 10, at 89; Sullivan, supra note 69, at 213; Negroes in Georgia Charge Vote Purge, N.Y. TIMEs, July 12, 1946, at 15; Negroes Vote Purge Halted in Georgia, N.Y. Times, July 14, 1946, at 29; Memorandum from Robert L. Carter (July 10, 1946), microformed on NAACP Papers, pt. IV, reel 7, fr. 725.

213. Adams v. Whittaker, 195 S.W.2d 634 (Ark. 1946). It is not clear why the Arkansas Legislature believed that Smith applied only to federal primaries, since the Fifteenth Amendment does not distinguish between state and federal elections. 
until lower courts had ruled Smith applicable to those states' primaries. ${ }^{214}$ Blacks did not participate in significant numbers in South Carolina primaries until Judge Waring's rulings in Elmore v. Rice and Brown v. Baskin. Waring threatened to hold party officials in contempt if they continued to bar black participation after he had made it clear, "once and for all, ... that they [would] be required to obey and carry out the orders of this court, not only in the technical respects but in the true spirit and meaning of the same." ${ }^{15}$ After Waring's rulings, 35,000 South Carolina blacks turned out to vote in Democratic primaries during the summer of $1948 .{ }^{216}$ In Louisiana, two federal court decisions from the early 1950s, enjoining registrars from discriminatory applications of voter registration requirements, opened the floodgates to a massive black voter registration. ${ }^{217}$

These lower court rulings, to repeat, were not ineluctable applications of existing precedent. The judges who decided these cases chose to extend Smith and to go beyond existing interpretations of the Fifteenth Amendment. As one contemporary commentator observed, these decisions adopted "broad and discerning" rather than "narrow and literal" interpretations of black voting rights, nullifying the repeated efforts of white Southerners to "find the magic combination of ambiguous wording, legalisms, and technicalities which will allow them to "make possible the impossible." 218 These judges took seriously the Supreme Court's admonitions in Classic that the Constitution is "not to be read with such stultifying narrowness" 19 and in Lane $v$. Wilson that the Fifteenth Amendment "nullifies sophisticated as well as simple-minded modes of discrimination."220

Moreover, not all of these lower court judges held the relatively progressive racial views of Judge Waring or Judge Wright (and Southern judges with such progressive racial views simply did not

214. See, e.g., Letter to Walter White (Feb. 16, 1946), microformed on NAACP Papers, pt. IV, reel 7, fr. 711 (Georgia); HINE, supra note 10, at 239; Letter from Attorney General Watson to Harry T. Moore (Feb. 19, 1946), microformed on NAACP Papers, pt. IV, reel 6, fr. 900 (Florida).

215. Brown v. Baskin, 78 F. Supp. 933, 942 (E.D.S.C. 1948), aff'd, 174 F.2d 391 (4th Cir. 1949)

216. Memorandum from C.B. Motley to Miss Karin (Apr. 7, 1949), microformed on NAACP Papers, pt. IV, reel 9, frs. 465-66; Boulware memorandum, supra note 154, at fr. 482; LAWSON, supra note 10, at 54.

217. FAIRCLOUGH, supra note 105, at 133-34.

218. The Right to Vote, supra note 82 , at frs. 554, 557.

219. United States v. Classic, 313 U.S. 299, 320 (1941)

220. Lane v. Wilson, 307 U.S. 268, 275 (1939). Lane invalidated, nearly a quarter century after the fact, Oklahoma's effort to grandfather the grandfather clause that the Supreme Court had invalidated in Guinn v. Oklahoma, 238 U.S. 347 (1915). On Guinn, see supra note 95. 
exist prior to World War II). ${ }^{221}$ By the late 1940s, even some less racially enlightened jurists were willing to interpret the law in ways that facilitated black suffrage. One Florida circuit judge who invalidated that state's white primary after Smith was a "cracker judge," according to local NAACP officials. ${ }^{222}$ Such judges almost certainly would not have interpreted an anti-segregation ruling of the Supreme Court with equal latitude, as their post-Brown behavior would confirm. ${ }^{223}$ But apparently, many Southern white judges shared the hierarchy of racial preferences embraced by the broader white community, which meant that they were far less resistant to black political participation than to school desegregation..$^{224}$

None of these conditions that combined to make Smith a momentous decision-greater white receptiveness to black voting; increased black assertiveness; broader NAACP presence; augmented threat of federal prosecution for voting rights violations; growing physical security of Southern blacks; and lower courts' willingness to support expansion of black suffrage-was itself simply a product of Smith. Thus, while the Court's intervention may have been an indispensable factor in mobilizing the huge black voter registration of the 1940s, Smith probably would not have been very significant in the absence of these supportive conditions.

Thus far we have considered the contributions of Smithcombined with certain favorable background social and political conditions - to Southern black voter registration in the 1940s. Two other points regarding Smith's impact warrant discussion. First, Smith affected the behavior of Southern whites as well as blacks. While the Court's ruling apparently inspired many Southern blacks to attempt to exercise their suffrage rights, it also mobilized Southern whites to

221. On Waring, see Tinsley E. Yarbrough, A Passion for Justice: J. Waties WARING AND CIVIL RIGHTS (1987). On Wright, see, for example, JACK BASS, UNLIKELY HEROES 112-35 (1981).

222. See Letter from Theodore Redding to Edward R. Dudley (Apr. 3, 1945), microformed on NAACP Papers, pt. IV, reel 6, fr. 974.

223. Compare Brown v. Baskin, 174 F.2d 391 (4th Cir. 1949) (Parker, J.) (extending Smith v. Allwright), with Briggs v. Elliot, 132 F. Supp. 776 (E.D.S.C. 1955) (Parker, J.) (narrowly construing Brown v. Board of Education). This was the same Judge Parker whose nomination to the Supreme Court was defeated in 1930, partially because of NAACP opposition, which was grounded in statements Parker had made opposing black suffrage in his gubernatorial campaign in North Carolina a decade earlier. On Parker's failed nomination, see KenNETH W. GoINGS, "ThE NAACP COMES OF AGE": THE DEFEAT OF Judge John J. PARKer (1990); Richard L. Watson, Jr., The Defeat of Judge Parker: A Study in Pressure Groups and Politics, 50 Miss. Valley Hist. Rev. 213 (1963). Some Southern judges simply refused to follow Brown. See, e.g., BASS, supra note 221, at 84-96; J.W. Peltason, Fifty Eight Lonely Men: Southern Federal Judges and School DESEGREGATION 7-8, 115-19 (1961).

224. See supra note 65 . 
oppose black political participation. ${ }^{225}$ Second, while Southern black voter registration after Smith rose to roughly twenty percent in 1952, a large majority of Southern blacks remained disfranchised. ${ }^{226}$ Southern blacks needed more than a Supreme Court ruling invalidating the white primary to enable them to exercise fully their rights of democratic citizenship.

The Justices sought to cushion the blow that Smith administered to Southern political traditions by reallocating the opinion-writing responsibilities from Felix Frankfurter, the Jewish Austrian immigrant from Harvard, to Stanley Reed, the native Kentuckian. ${ }^{227}$ That small concession to Southern sensibilities proved inefficacious. Many Southern Democrats trumpeted their defiance of Smith, warning fellow white Southerners that elimination of the white primary would jeopardize segregation and racial purity. ${ }^{228}$ Senator John Holmes Overton of Louisiana thundered that "[t]he South, at all costs, will maintain the rule of white supremacy." 229 Even Florida Senator Claude Pepper, one of the most liberal politicians in the South, breathed defiance when the decision in Smith was announced in the midst of his tough primary battle in April, 1944: "The South will allow nothing to impair white supremacy." ${ }^{230}$ Democratic Party officials throughout the Deep South insisted that Smith would not affect their white primary policies. ${ }^{231}$ In fact, as we have seen, party officials did not permit blacks to vote in Democratic primaries in most counties of Florida, South Carolina, Georgia, Alabama, Louisiana, and Mississippi for at least a year or two after Smith. ${ }^{232}$ Southern newspapers cautioned that it was one thing for the Court to issue its edict and

225. Lawson and Tushnet both understate the extent of the post-Smith backlash. LAWSON, supra note 10, at 46 (calling the Southern response to Smith "remarkably calm"); TUSHNET, supra note 91, at 107 (endorsing Lawson's assessment).

226. LAWSON, supra note 10, at 139 tbl.1.

227. See Alpheus Thomas Mason, Harlan Fiske Stone: Pillar of the LaW 614-15 (1956).

228. For enraged Southern responses to Smith, see Lewis Wood, Ruling on Texas Voting Arouses Southern Race, N.Y. Times, Apr. 9, 1944, at 6E; Arthur Krock, South's Devices Run Thin, N.Y. TIMEs, Apr. 5, 1944, at 12; Outspoken Against Negro Participation in Primaries, ARK. GAZETTE (undated), microformed on NAACP Papers, pt. IV, reel 6, fr. 676. For the larger threat posed by elimination of the white primary, see Political advertisement for Roy Harris, AUGUSTA Chron. (Apr. 13, 1946), id. pt. IV, reel 7, frs. 433-36.

229. Time Bomb, supra note 111 , at 21.

230. Id.; see also Gary R. Mormino, GI Joe Meets Jim Crow: Racial Violence and Reform in World War II Florida, 73 FLA. HIST. Q. 23, 39-40 (1994) (noting Pepper's statement). For other criticism of Smith by Southern politicians, see Wood, supra note 195, at 1.

231. See, e.g., Southern Leaders Prepare to Resist, supra note 97, at 15; Further Legal Battles Likely on Negro's Primary Vote Right (unidentified press clipping) (Apr. 4, 1944), microformed on NAACP Papers, pt. IV, reel 7, fr. 583; Letter from Malcolm E. Lafargue to Daniel E. Byrd (Oct. 23, 1947), id. pt. IV, reel 8, fr. 529; Letter from John L. LeFlore to Milton R. Konvitz (Apr. 12, 1944), id. pt. IV, reel 6, frs. 302-03; Letter from Arthur D. Shores to Thurgood Marshall (May 3, 1944), id. pt. IV, reel 6, fr. 67.

232. See supra notes $214-17$ and accompanying text. 
quite another to enforce it, especially when the decision augured "a political and social revolution." 233 Southern white citizens warned that "you can[']t push nigger equality on the South without a fight." 234

In some Southern states, Smith inspired efforts to suppress black voter registration. As we have seen, Alabama enacted the Boswell amendment to confer virtually unfettered discretion on registrars to reject black applicants, and Georgia likewise adopted more stringent registration requirements. ${ }^{235}$ As elimination of the white primary inspired more blacks to register, public officials became more intransigent, strictly interpreting registration requirements whether or not state law authorized them to do so. Emory Jackson, secretary of the NAACP's Birmingham branch, reported early in 1945 that local registrars were "getting worse" since Smith, and as a result the drive to register black voters did not "seem to be making much headway." ${ }^{36}$ The NAACP's branch secretary in Marion County, Florida, observed late in 1945 that Southern whites had grown increasingly resigned to opening Democratic primaries to black participation and now were employing alternative methods to preserve white political supremacy, such as fraud, economic intimidation, and physical violence. ${ }^{237}$ Late in 1947 the executive committee of the Caddo Parish, Louisiana, Democratic Party rescinded its resolution excluding blacks from party primaries, but the parish registrar refused to enroll blacks unless they produced three white vouchers who were personally known to the registrar and resided in the same precinct as the registrantvirtually impossible requirements for blacks to meet. ${ }^{238}$

The political backlash against Smith was greatest in South Carolina and Mississippi, the two southern states with the largest black population percentages. Senator Burnet Maybank of South Carolina warned his Senate colleagues a few days after Smith that white Southerners "will not accept these interferences" and that "we of the

233. Editorial, Theory Versus Condition (unidentified Georgia newspaper) (Apr. 4, 1944), microformed on NAACP Papers, pt. IV, reel 7, fr. 585.

234. Letter from H.L. Hunnicutt to Claude Dempsey (Feb. 21, 1945), id. pt. IV, reel 6, fr. 693.

235. See supra notes 204-05 and accompanying text.

236. Letter from Emory O. Jackson to Thurgood Marshall (Feb. 8, 1945), microformed on NAACP Papers, pt. IV, reel 6, fr. 116; see also Letter from Emory O. Jackson to Thurgood Marshall, supra note 164, at fr. 131; unidentified press clipping, supra note 129, at fr. 274.

237. Letter from John A. Buggs to Thurgood Marshall (Dec. 18, 1945), microformed on NAACP Papers, pt. IV, reel 6, fr. 892.

238. See Letter from Daniel E. Byrd to Thurgood Marshall (Nov. 6, 1947), id. pt. IV, reel 8, fr. 531; Letter from Donald Jones to Tom Clark (Nov. 24, 1947), id. pt. IV, reel 8, fr. 535. See also Letter from Chair of Alexandria, La., Branch Legal Committee to NAACP, supra note 158, at fr. 424; Letter from Thurgood Marshall to Francis J. Biddle, supra note 211 , at fr. 433 . 
South will maintain our political and social institutions as we believe to be in the best interest of our people." ${ }^{339}$ Governor Olin Johnston called the South Carolina Legislature into special session a few days later. ${ }^{240}$ Announcing that "[h]istory has taught us that we must keep our white Democratic primaries pure and unadulterated,"241 Johnston urged the repeal of all 150 state laws regulating the Democratic Party, which on one reading of Smith would enable the party to continue operating a white primary without violating the Constitution. ${ }^{242}$ Should wholesale deregulation of the party fail, Johnston ominously warned, "we South Carolinians will use the necessary methods to retain white supremacy in our primaries and to safeguard the homes and happiness of our people." ${ }^{43}$ Johnston concluded: "White supremacy will be maintained in our primaries. Let the chips fall where they may!" ${ }^{44}$

Likewise in Mississippi, Smith invigorated those whites most committed to preserving white political supremacy. The Jackson Daily News warned the Justices that they were badly mistaken if they believed blacks would vote in Mississippi Democratic primaries. ${ }^{245}$ If any foolish person doubted this, "let "em try." 246 The worst manifestation of the Smith backlash materialized in Mississippi two years later. ${ }^{247}$ The combination of Smith and the aggressive effort of Southern blacks to implement it created a golden opportunity for white supremacist politicians. ${ }^{248}$ With Mississippi blacks seeking to register in unprecedented numbers, Senator Theodore Bilbo, running for reelection in the 1946 Democratic primary, invoked the specter of "Negro domination" in a state that had just (barely) ceased for the first time in a century to have a black majority. ${ }^{249}$ In a widely reported campaign speech, Bilbo exhorted every "red-blooded white

239. Cushman, supra note 197, at 75; C.P. Trussell, South Won't Open Polls to Negroes, Maybank Warns, N.Y. TIMES, Apr. 14, 1944, at 1.

240. Proclamation of Gov. Olin T. Johnston (Apr. 12, 1944), microformed on NAACP Papers, pt. IV, reel 10, fr. 481.

241. Olin T. Johnston, Speech to Joint Assembly and General Assembly of South Carolina (Apr. 14, 1944), id. pt. IV, reel 10, frs. 481-82.

242. Id.

243. Id. at fr. 482 .

244. Id.

245. Supreme Court Rules Out White Primaries, 51 The CRISIS 164, 165 (May 1944).

246. Id. at 165 .

247. For a similar effort by former governor Eugene Talmadge to capitalize on Smith in Georgia, see Tinder for Talmadge, NEWSWEEK, July 1, 1946, at 22, microformed on NAACP Papers, pt. IV, reel 7, fr. 723; Three States Top Week's Primaries, N.Y. Times, July 15, 1946, at 1; AlEXANDER HEARD, A TWO-PARTY SOUTH? 192 (1952); SUllivaN, supra note 69, at 211; Joseph L. Bernd, White Supremacy and the Disfranchisement of Blacks in Georgia, 1946, 66 GA. HisT. Q. 492, 494-98 (1982).

248. See FAIRCLOUGH, supra note 105, at 136; SUlLIVAN, supra note 69 , at 7.

249. DiTTMER, supra note 127, at 2; LAWSON, supra note 10, at 99-100; Lewis, supra note 203 , at 329,332 . 
man to use any means to keep the niggers away from the polls." 250 Declining explicitly to advocate violence, Bilbo slyly observed that "you know and I know what's the best way to keep the nigger from voting. You do it the night before the election. I don't have to tell you any more than that. Red-blooded men know what I mean."251 Throughout the state, enthusiastic supporters took the Senator at his word. ${ }^{252}$ Crosses were burnt in Jackson. In Biloxi, a sign at a street intersection warned blacks to "vote at your own risk." In Pucket, Mississippi, four whites beat a black man and threatened to kill him for attempting to register. Whites brandishing pistols repulsed Medgar Evers and four other black veterans from the polls in Decatur, Mississippi.

Of course, the backlash created by Smith could generate its own counterbacklash. Mississippi Democrats could get away with threatening and deploying deadly force against prospective black voters in 1875 or even 1935 , but no longer by 1945 . Dominant public opinion in the nation simply could not bear Bilbo's thinly veiled exhortations to violence. A white man from McAlester, Oklahoma, informed Bilbo that his speech was reminiscent of sentiments emanating from that "late departed and unlamented jerk in Germany" and admonished the Senator that " $\mathrm{t}]$ he time for this narrow-minded race hatred stuff is out." ${ }^{253}$ Bilbo unwittingly had challenged the Federal Government to prove that it had the inclination and capacity to enforce a Supreme Court decision against an obstreperous southern state. ${ }^{254}$ The United States Senate had little choice but to conduct investigative hearings, which took place under the chairmanship of Louisiana Senator Allen Ellender in early December $1946 .{ }^{255}$ Those hearings had an important educational effect on Northern opinion, as well as a motivational impact on Mississippi blacks. The Northern Senators on the Ellender committee were shocked by the revelations of force and fraud used by white Mississippians to defeat black suffrage. A Washington Post editorial noted that it was impossible to read the Senate committee's re-

250. Lewis, supra note 203, at 332.

251. LAWSON, supra note 10, at 100.

252. NAACP, Negro Vote in Southern States (undated), microformed on NAACP Papers, pt. IV, reel 8, frs. 862, 868-69 [hereinafter Negro Vote]; see also Letter from Rev. George T.J. Strype to Lamarr Caudley (July 2, 1946), id. pt. IV, reel 9, frs. 57-58; DITTMER, supra note 127 , at $1-3$; LAWSON, supra note 10 , at 103.

253. Letter from H.W. Polson to Sen. Bilbo (June 23, 1946), microformed on NAACP Papers, pt. IV, reel 9, frs. 31-32.

254. See Letter from Daniel E. Byrd to Thurgood Marshall (July 3, 1946), id. pt. IV, reel 9, frs. 49-50; Letter from Daniel E. Byrd to Thurgood Marshall (July 6, 1946), id. pt. IV, reel 9, fr. 60 .

255. This account of the Senate committee's investigation of Bilbo's 1946 Senate primary campaign is distilled from Probes: Votes and The Man, NewsweEK, Dec. 16, 1946, at 33-34; DiTTMER, supra note 127, at 3-9; LAWSON, supra note 10, at 105-14; Lewis, supra note 203 , at $332-39$. 
port on Bilbo without "a sense of sickness" at the outright brutality displayed. ${ }^{256}$ Nearly 200 Mississippi blacks-many of them World War II veterans, some wearing their good conduct medals-showed up as volunteer witnesses at the Senate committee hearings conducted in Jackson to testify to the physical violence they had endured for attempting to exercise their federal constitutional rights. ${ }^{257}$ Many more Mississippi blacks expressed renewed determination to enjoy the benefits of democratic citizenship by appearing at registrars' offices. Black voter registration in Mississippi rose by fifty percent in the year following the Bilbo hearings. Other incidents involving violent (indeed deadly) suppression of the efforts of Southern blacks to vote in the late 1940s likewise proved to have "terrific publicity value" for the voter registration campaign. ${ }^{258}$ It was one thing to use obfuscation to prevent Southern blacks from voting; it was quite another to use deadly force.

Much as public opinion was repulsed by the use of violence to suppress black suffrage in Mississippi, so was judicial opinion alienated by the persistent use of evasive tactics to circumvent Smith in South Carolina. Judge Waring became infuriated as state Democratic officials responded to his rulings with further efforts at circumvention. When South Carolina repealed all of its statutes regulating political parties after Smith, Judge Waring decreed that the time had come for the state to "rejoin the Union," and he ordered party officials to allow blacks to vote in primaries. ${ }^{259}$ They responded instead by adopting a dual party membership status based on race and a loyalty oath designed to offend prospective black members. A furious Judge Waring invalidated these new party rules and declared that "the time has come when racial discrimination in political affairs [has] got to stop." ${ }^{260} \mathrm{He}$ did not "care whether there [were] any people who agree[d] with [him]"; ${ }^{261}$ South Carolina must obey the law of the

256. Editorial, Bilboism, WASH. PosT, Dec. 6, 1946, at 18.

257. Probes: Votes and The Man, supra note 255, at 33-34; see also DITTMER, supra note 127, at 8-9; LAWSON, supra note 10, at 112-14. Southern Democrats, enjoying a majority on the Ellender committee, refused to hold Bilbo responsible for the violence that had pervaded his election contest. The Republican minority on the committee dissented. However, the new Congress that convened in January 1947 had a Republican majority that refused to seat Bilbo. A compromise was reached, under which Bilbo's credentials were laid on the table while the Senator took a leave of absence owing to ill health. He died later in 1947 , thus mooting the issue of whether to seat him.

258. Letter from Franklin H. Williams to A.T. Walden (Oct. 25, 1948), microformed on NAACP Papers, pt. IV, reel 8, fr. 316; see also Memorandum from Roy Wilkins to Walter White (Nov. 3, 1948), id. pt. IV, reel 8, fr. 320.

259. Elmore v. Rice, 72 F. Supp. 516, 528 (E.D.S.C. 1947); see supra notes 76-79 and accompanying text.

260. Transcript of statement by Judge Waring in Brown v. Baskin (July 16, 1948), microformed on NAACP Papers, pt. IV, reel 9, frs. 636-38 [hereinafter Waring Transcript]. See also KEY, supra note 114, at 631.

261. Waring Transcript, supra note 260, at fr. 638 . 
land. Waring warned that any future violations of the letter or spirit of his order were "going to be punished by imprisonment." 262 One wonders if Supreme Court Justices, observing party and public officials evading High Court rulings, might have shared Waring's growing irritation, as well as his determination to expand legal interpretations where necessary to counter Southern efforts at circumvention. Certainly the Justices' willingness to find unconstitutional state action in Terry $v$. Adams is consistent with that hypothesis. ${ }^{263}$

In sum, while Smith generated a white supremacist backlash in Deep South politics, the violence and evasion that ensued generated their own counterbacklashes. National opinion by the mid-1940s no longer countenanced the violent suppression of black suffrage in Mississippi. Revulsion against this sort of brutality contributed significantly to the development of a national civil rights consciousness in the postwar years, which in turn influenced President Truman's racial policies. ${ }^{264}$ Moreover, the fraudulent evasive tactics of public and party officials after Smith inspired a similar backlash in judicial opinion, as federal judges tired of the seemingly endless capacity of Southern officials to devise new methods of obstructing black suffrage.

Notwithstanding the impressive gains made in black voter registration in the postwar period, black voting in the South remained confined largely to cities and towns. In rural areas, especially in the Deep South, the overwhelming majority of blacks remained disfranchised. ${ }^{265}$ Thus, for example, while an estimated 22,000 blacks were registered to vote in Atlanta by $1946,{ }^{266}$ in dozens of Deep South counties, many of which had black majorities, not a single black person was registered to vote. ${ }^{267}$ In Louisiana, black voter registration had exploded in 1948 from 8,000 to 43,000, yet roughly fifty percent of those black voters lived in New Orleans, and in half of the state's

262. $I d$.

263. 345 U.S. 461 (1952); see supra notes 88-91 and accompanying text.

264. See, e.g., Donald R. MCCoy \& RICHARD T. RueTten, Quest And Response: Minority Rights and the TRuman Administration 42-54 (1973); To SEcure These Rights: The REPORT OF THE PRESIDENT'S COMMISSION ON CIVIL RIGHTS 20-27 (1947); Kari Frederickson, "The Slowest State" and "Most Backward Community": Racial Violence in South Carolina and Federal Civil-Rights Legislation, 1946-1948, 98 S.C. HIST. MAG. 177 (1997).

265. On the contrast between the urban and rural South, see FAIRCLOUGH, supra note 105, at 123-24; KEY, supra note 114, at 522; LAWSON, supra note 10, at 129-30; Emmons, supra note 106, at 237; Negro Vote, supra note 252; Tureaud memorandum, supra note 142 , at frs. 407-09.

266. Negro Vote, supra note 252, at fr. 867.

267. See, e.g., GARROW, supra note 92, at 9 (noting the existence of fourteen Mississippi counties that did not have a single registered black voter in 1955); LAWSON, supra note 10, at 130 (noting the existence of two dozen black-belt counties in the Deep South where not a single black person was registered to vote in 1952); Bernd, supra note 247, at 500. 
sixty-four parishes, not a single black person voted. ${ }^{268}$ Well over 100,000 blacks had registered to vote in Georgia by 1948, and roughly 300,000 had enrolled in Texas, yet Mississippi and Alabama showed "no progress," ${ }^{69}$ as black voter registration in those states was limited to a paltry 3,000 and 8,000, respectively. ${ }^{270}$

One of the most formidable obstacles to black voting in the rural South remained the threat and reality of physical violence. In the mid-1940s the South was a less violent place for blacks asserting their constitutional rights than it had been even ten years earlier, ${ }^{271}$ but it was still plenty violent. While blacks in Florida cities had registered in large numbers by the late $1940 \mathrm{~s}$, prospective black voters in rural parts of the state had to endure KKK intimidation, letters warning that those who dared to vote would "be floating up and down the river," ${ }^{272}$ and shots fired into their homes. ${ }^{273}$ Tens of thousands of blacks registered to vote in Louisiana's urban parishes, while most rural blacks remained "afraid to even try to register because of repeated examples of brutality and threatened acts against their physical safety." ${ }^{274}$ Rural blacks in Louisiana received written notes from the KKK threatening to put black voters "out of business" 275 and warnings that whites were "figuring on raising Hell" 276 if blacks turned out at the polls. Sheriffs and deputy sheriffs in rural Alabama terrorized blacks who dared attempt to register. ${ }^{277}$ Thousands of blacks voted with little resistance in Georgia cities such as Atlanta, Savannah, and Augusta by 1946, but rural blacks had to endure KKK intimidation and warnings that any black man who voted

268. Weber, Citizenship, supra note 101, at fr. 550; see also FAIRCLOUGH, supra note 105, at 123-24 (providing a lower number for black voter registration in Louisiana).

269. Weber, Citizenship, supra note 101, at fr. 552.

270. Id. at fr. 549. For a slightly different estimate for Mississippi, see Lewis, supra note 203 , at 334 .

271. See supra notes $180-87$ and accompanying text.

272. Letter from unidentified author in Milton, Florida, to NAACP (Apr. 14, 1948), microformed on NAACP Papers, pt. IV, reel 6, fr. 936.

273. Statement of Deacon Smith (undated), id. pt. IV, reel 6, frs. 910-11; Letter from Harry T. Moore to Gov. Willard F. Caldwell (Apr. 20, 1948), id. pt. IV, reel 6, fr. 941; Letter from Eldridge G. Brooks to NAACP (July 19, 1948), id. pt. IV, reel 6, fr. 946.

274. Tureaud memorandum, supra note 142, at fr. 409.

275. Letter from A.P. Tureaud to Justice Department (Jan. 17, 1948), microformed on NAACP Papers, pt. IV, reel 8, fr. 569.

276. Letter from Rev. John Allum to NAACP (Feb. 4, 1948), id. pt. IV, reel 8, frs. 57980. For more Louisiana examples, see Letter from A.P. Tureaud to Justice Department (Jan. 23, 1948), id. pt. IV, reel 8, fr. 573; Letter from A.P. Tureaud to J. Skelly Wright (July 29, 1948), id. pt. IV, reel 8, fr. 590; Letter from Herbert Monte Levy to Thurgood Marshall (June 30, 1950), id. pt. IV, reel 8, fr. 615.

277. Letter from Emory O. Jackson to Thurgood Marshall, supra note 207, at frs. 25354; Letter from Clayborn Williams et al., to "To Whom it May Concern" (Dec. 7, 1949), microformed on NAACP Papers, pt. IV, reel 6, frs. 250-51. 
would be "a dead Nigger." 278 Most rural Georgia blacks heeded gubernatorial candidate Eugene Talmadge's warnings to stay away from the polls. In Mississippi, even the cities remained dangerous. The editor of a black newspaper in Jackson reported that fear was the reason why only 315 of the 40,000 blacks living in that city registered to vote in $1946 .{ }^{279}$ The Jackson Daily News published the names of blacks who were prominent in the Mississippi Progressive Voters League and warned that the best way "to prevent unhealthy and unhappy results" was for blacks to stay away from Democratic primaries. ${ }^{280}$

Prospective black voters in the rural Deep South had good reason to be frightened. A recently discharged veteran, Etoy Fletcher, tried to register in rural Mississippi in 1946. The registrar informed him that "Niggers are not allowed to vote in Rankin County, and if you don't want to get into serious trouble get out of this building . . ."281 While waiting for a bus out of town, Fletcher was assaulted by four white men who drove him several miles into the woods, "beat[ ] and flogged [him] mercilessly," and threatened to kill him if he ever again attempted to vote. ${ }^{282}$ Many other aspiring black voters in Mississippi reported similar assaults during the summer of $1946,{ }^{283}$ as "everything short of murder" 284 was perpetrated upon them. In Gadsden County, Florida, two black half-brothers, J.T. Smith and Harry Moody, helped mobilize 150 blacks to register in 1947 and 1948. Then, ignoring warnings from several whites, they turned out at the polls themselves in May, 1948. As a result, one of them had his home blown up, crippling one of his children, and both of them were run out of town. ${ }^{285}$ In Montgomery County, Georgia, D.V. Carter organized an NAACP branch in 1946 consisting mainly of farmers and sharecroppers and devoted principally to voter registration activities. $^{286}$ Several hundred blacks registered as a result of these efforts. After ignoring repeated threats from the KKK to desist from his suf-

278. Letter from C.L. Jordan to NAACP (Jan. 29, 1948), microformed on NAACP Papers, pt. IV, reel 8, fr. 215; see Negro Vote, supra note 252, at fr. 867.

279. See Probes: Votes and The Man, supra note 255, at 33.

280. JACKSON DAILY NEWS (undated), microformed on NAACP Papers, pt. IV, reel 8, fr. 892.

281. Etoy Fletcher Affidavit (June 15, 1946), id. pt. IV, reel 8, fr. 894.

282. Id.

283. See, e.g., Statement of V.R. Collier (July 2, 1946), microformed on NAACP Papers, pt. IV, reel 9, frs. 51-56; Letter from Robert L. Carter to Tom Clark (July 1, 1946), id. pt. IV, reel 9, fr. 47.

284. Letter from V.R. Collier to NAACP (July 8, 1946), id. pt. IV, reel 9, fr. 61.

285. See Letter from J.T. Smith to Walter White (May 11, 1948), id. pt. IV, reel 6, frs. 762-65; Letter from D.H. Spencer to Mrs. Black (May 12, 1948), id. pt. IV, reel 6, frs. 76768; Smith Affidavit (June 1, 1948), id. pt. IV, reel 6, frs. 779-81; Letter from Harry T. Moore to Thurgood Marshall, supra note 169, at fr. 791; Emmons, supra note 106, at 241.

286. Memorandum from Franklin H. Williams to Henry Lee Moon (Nov. 26, 1948), microformed on NAACP Papers, pt. IV, reel 7, frs. 883-86. 
frage activities, Carter was severely beaten in 1948. Isaac Nixon, whom Carter had persuaded to vote, was murdered for doing so. ${ }^{287}$ An all-white jury acquitted the two white brothers responsible for killing Carter. ${ }^{288}$ In Louisiana in 1951, a white deputy sheriff killed, allegedly in self-defense, a black man who happened to be one of the plaintiffs in an NAACP voting rights case. ${ }^{289}$ Harry Moore, founder of Florida's Progressive Voters League, was assassinated by a bomb planted in his home on Christmas night, 1951-possibly in retaliation for his voting rights work. ${ }^{290}$

While the Justice Department was more attentive to NAACP concerns by the late 1940s, it remained reluctant to prosecute public and party officials who obstructed black voting. Democratic administrations in Washington, D.C., had political incentives not to prosecute Southern Democrats, because doing so might "translate impotent rumblings against the New Deal into actual revolt at the polls." ${ }^{291}$ Moreover, Southern United States attorneys, especially if ambitious for elective office, were not eager to prosecute voting cases. ${ }^{292}$ Even for those who were, these cases proved difficult to win. Prosecutors had trouble locating witnesses, as local communities protected culprits behind a veil of silence. ${ }^{293}$ Most importantly, local white jurors simply would not convict registrars or party officials for adhering to traditional mores rejecting black suffrage. ${ }^{294}$ Thus, the NAACP's constant pressure on the Justice Department to prosecute voting cases

287. Letter from Dr. Ralph Mark Gilbert to Franklin H. Williams (Oct. 14, 1948), id. pt. IV, reel 7 , fr. 867 .

288. See id. at fr. 867; Memorandum from Franklin H. Williams to Henry Lee Moon, supra note 286, at frs. 883-86; Georgia Negro Was Slain for Voting, N.Y. TIMES (Sept. 12, 1948), microformed on NAACP Papers, pt. IV, reel 8, fr. 288; Letter from A.T. Walden to Franklin H. Williams (Oct. 21, 1948), id. pt. IV, reel 8, frs. 312-13.

289. Along the N.A.A.C.P. Battlefront, 58 The CRISIS 674 (Dec. 1951); FAIRCLOUGH, supra note 105 , at $130-31$.

290. On Moore's unsolved murder, see GREEN, supra note 130, at 1-15, 172-226. Moore was involved in all aspects of the civil rights struggle in Florida. There is no way of knowing whether he was killed for his voting rights work or, for example, because of his efforts to secure justice in the infamous Groveland case. The best treatment of Groveland is Lawson et al., supra note 106.

291. Quotation from Roosevelt's race relations adviser, Jonathan Daniels, in LAWsON, supra note 10 , at 47 .

292. See, e.g., Letter from Malcolm E. Lafargue to Daniel E. Byrd, supra note 231, at fr. 529; Statement of V.R. Collier, supra note 283, at frs. 51-56; Telegram from Thurgood Marshall to Wendell Burge (May 21, 1941), microformed on NAACP Papers, pt. IV, reel 10, fr. 600; 3 Cherokee Men Cleared by Jury (unidentified and undated newspaper clipping), id. pt. IV, reel 9, fr. 609; To SECURE THESE RIGHTS, supra note 264, at 121.

293. See, e.g., Letter from Alexander M. Campbell to Franklin H. Williams (Nov. 30, 1948), microformed on NAACP Papers, pt. IV, reel 6, fr. 794; Letter from Alexander M. Campbell to Thurgood Marshall (May 22, 1949), id. pt. IV, reel 7, frs. 1038-39.

294. See, e.g., Letter from Lottie P. Gaffney to Thurgood Marshall, supra note 159, at frs. 644-45; 3 Cherokee Men Cleared by Jury, supra note 292, at fr. 609. For the Justice Department's conviction that it could not win such cases, see CARR, supra note 34, at 149 , 178. 
went for naught - to the great frustration of the Association, which had deferred numerous civil lawsuits on the view that criminal prosecutions should take priority. ${ }^{295}$ NAACP officials believed that they had a "distinct understanding" 296 with the Justice Department that it would prosecute voting cases in 1944-45, and they had ample reason for concluding that the Department was "doubledealing." ${ }^{297}$ Even in cases of patent constitutional violations, the Department refused to prosecute. Where prospective black voters had been beaten or killed, the Department conducted investigations, but even in these cases no prosecutions resulted. ${ }^{298}$ In the end, the empty threat of federal prosecution proved inadequate to deter those Southern whites who were committed to obstructing black suffrage through force or fraud.

Violence and the Justice Department's failure to prosecute it were not the only obstacles to black voting in the rural Deep South. Blacks daring to exercise their suffrage rights faced likely economic retaliation, which posed a special problem in rural areas where blacks were almost entirely dependent upon whites for employment (unlike in Southern cities, where the segregated economy had produced a class of black professionals-doctors, dentists, undertakers, and ministers-who were largely independent of white economic pressure). ${ }^{299}$ Public officials in Mobile, Alabama, struggled mightily to have John LeFlore, the energetic chairman of the NAACP's Regional Conference of Southern Branches, fired from his job with the United States

295. For NAACP pressure on the Justice Department, see Letter from Robert L. Carter to Tom Clark (July 16, 1946), microformed on NAACP Papers, pt. IV, reel 9, fr. 74; Letter from Thurgood Marshall to Tom Clark, supra note 159, at frs. 236-37; Emmons, supra note 106, at 240-41; see also supra notes 162-67 and accompanying text. For the NAACP's deferral of civil lawsuits, see, for example, Letter from Thurgood Marshall to A.T. Walden (Sept. 25, 1944), microformed on NAACP Papers, pt. IV, reel 7, fr. 625; Letter from Thurgood Marshall to John L. LeFlore (Dec. 11, 1945), id. pt. IV, reel 6, fr. 550; Letter from C.A. Scott \& Wallace Van Jackson to Thurgood Marshall (Aug. 26, 1944), id. pt. IV, reel 8, frs. 83-84.

296. Letter from Thurgood Marshall to C.A. Scott (Dec. 6, 1944), microformed on NAACP Papers, pt. IV, reel 7, fr. 630.

297. Letter from Daniel E. Byrd to Robert L. Carter (July 30, 1946), id. pt. IV, reel 9, fr. 80; see Letter from C.A. Scott to Thurgood Marshall (Apr. 29, 1945), id. pt. IV, reel 9, fr. 648; LAWSON, supra note 10, at 48-49. For further evidence of Department assurances that it would prosecute, see Letter from Thurgood Marshall to C.A. Scott (Dec. 14, 1944), microformed on NAACP Papers, pt. IV, reel 9, fr. 633; Letter from A.T. Walden to Thurgood Marshall (Sept. 1, 1944), id. pt. IV, reel 8, frs. 91-92; Letter from A.T. Walden to Francis J. Biddle, supra note 71, at fr. 637.

298. See, e.g., LAWSON, supra note 10, at 119.

299. On economic retaliation, see, for example, Letter from Lottie A. Gaffney to NAACP (June 4, 1942), microformed on NAACP Papers, pt. IV, reel 10, frs. 666-69. On the benefits of the segregated urban economy, see, for example, MYRDAL, supra note 65, at 304-10; George C. Wright, Life Behind A Veil: Blacks IN Louisville, KentuCKY 18651930 , at $220-28(1985)$. 
Postal Service in retaliation for his voter registration activity. ${ }^{300}$ Nor were lawsuits to vindicate constitutional suffrage rights a realistic option for indigent rural blacks. ${ }^{301}$ Even those who could afford to sue might not be able to find a lawyer willing to take voting rights cases. Very few black lawyers practiced in the rural South, and many white lawyers remained reluctant to challenge black disfranchisement. ${ }^{302}$

Moreover, litigation challenging the political status quo in the rural Deep South entailed possible risks, both for clients and attorneys. ${ }^{303}$ A black lawyer named Arthur Madison, who sued to compel Montgomery County, Alabama, registrars to enroll black applicants in 1944, was arrested, convicted, and then summarily disbarred for representing clients without authorization. ${ }^{304}$ The county sheriff had intimidated Madison's clients into withdrawing their consent to his representation. ${ }^{305}$ No white lawyers were willing to defend Madison at his trial. In another incident, a black minister from Louisville, Mississippi, informed the NAACP of his unsuccessful effort to vote in the Democratic primary in July $1946 .{ }^{306} \mathrm{He}$ wanted the Justice Department informed, but because of "the social condition of the Deep south," ${ }^{307}$ he did not want his name used publicly until it was time to testify in court, because publicity would put his life in jeopardy. Finally, such lawsuits, even if they could be brought without inciting retaliation, were hardly a cinch to win. Many federal judges by the early 1950s were willing to enjoin registrars from engaging in racially discriminatory practices, but were not yet prepared to invalidate vaguely worded literacy tests or to command that particular

300. Letter from John L. LeFlore to Thurgood Marshall (Feb. 5, 1946), microformed on NAACP Papers, pt. IV, reel 6, frs. 551-52; Schnell Accuses Negroes' Leader, MoBILE PRESS (Feb. 1, 1946), id. pt. IV, reel 6, fr. 553.

301. See, e.g., Letter from Daniel E. Byrd to Robert L. Carter (July 6, 1947), id. pt. IV, reel 9 , frs. 115-16.

302. On the paucity of black lawyers, see, for example, MYRDAL, supra note 65 , at 550; Charles H. Houston, The Need for Negro Lawyers, 4 J. NEGRo EdUc. 49, 50 tbl.1 (1935). On the reluctance of white lawyers to take such cases, see supra note 152.

303. For threats against white lawyers, see Letter from Harry T. Moore to C.A. Smith (May 26, 1948), microformed on NAACP Papers, pt. IV, reel 6, frs. 942-43. For intimidation of prospective black litigants, see Letter from Daniel E. Byrd to T. Vincent Quinn (Dec. 16, 1947), id. pt. IV, reel 8, frs. 551-52.

304. Letter from John L. Leflore to Thurgood Marshall (Apr. 9, 1944), id. pt. IV, reel 6, fr. 293; Letter from Arthur D. Shores to Thurgood Marshall (Apr. 22, 1944), id. pt. IV, reel 6, fr. 315; Held in Negro Vote Case, N.Y. Times, Apr. 10, 1944, at 21.

305. Letter from Thurgood Marshall to Tom Clark (May 1, 1944), microformed on NAACP Papers, pt. IV, reel 6, fr. 321.

306. Letter from Rev. C.N. Eiland to Walter White (July 16, 1946), id. pt. IV, reel 9, fr. 73.

307. Id.; see also Letter from Thurgood Marshall to C.A. Smith (Feb. 11, 1947), id. pt. IV, reel 9, fr. 108 (noting that NAACP representatives in Mississippi were "unwilling to permit their names to be used in any investigation"). 
black applicants be registered, for fear of usurping registrars' authority. ${ }^{308}$

Blacks in the rural South would not vote in significant numbers until further interventions by the Supreme Court and, more importantly, by Congress and the President-developments that did not take place for the most part until the 1960s. Only the federal executive could secure the physical safety of black voters in the Deep South. Only Congress could lift the burden of litigating voting rights violations from the shoulders of individual blacks and place it on the Federal Government by empowering the Attorney General to seek injunctions against registrars who practiced race discrimination-a remedy that also had the advantage of avoiding (white) Southern juries. ${ }^{309}$ More importantly, only Congress could threaten to replace local registrars with federal officials if discrimination against black registrants did not cease. ${ }^{310}$ The Supreme Court in 1966 finally invalidated the poll tax in the few Southern states that continued to employ that suffrage restriction. ${ }^{311}$ Yet because the Court continued to reject constitutional challenges to literacy tests as late as 1959, further congressional intervention was necessary to eliminate that obstacle to black voter registration. ${ }^{312}$

Smith v. Allwright, in conjunction with receptive social and political conditions, launched a racial revolution in Southern politics. But it could not overcome the obstacles to black voting in the rural Deep South. Only intervention by the political branches of the National Government could secure to all Southern blacks the right to participate in politics on the same terms as Southern whites. That intervention was mainly a product of the 1960 s civil rights movement. ${ }^{313}$

308. See, e.g., Byrd v. Brice, 104 F. Supp. 442, 443 (W.D. La. 1952) (refusing to order the complainant registered, because to do so "would be usurpation by [the court] of the discretionary function of the registrar").

309. Civil Rights Act of 1957, Pub. L. No. 85-315, § 131(c), 71 Stat. 634, 637-38 (codified as amended at 42 U.S.C. $§ 1971(c)$ (1994)). On the 1957 Act's provision empowering the Justice Department to seek injunctive relief, see LAWSON, supra note 10, at 120-21, 349 .

310. Civil Rights Act of 1965, Pub. L. No. 89-110, § 3(a), 79 Stat. 437, 437 (codified as amended at 42 U.S.C. § 1973a(a) (1994)).

311. Harper v. Va. Bd. of Elections, 383 U.S. 663 (1966). On the continued disfranchising effect of the poll tax, see KEY, supra note 114, at 608 (estimating that repeal of the poll tax increases voter turnout by about five percent to ten percent); OGDEN, supra note 62, at 135-36 (same).

312. Lassiter v. Northampton County Bd. of Elections, 360 U.S. 45 (1959); Civil Rights Act of 1965, Pub. L. No. 89-110, § 3(b), 79 Stat. 437, 437 (codified as amended at 42 U.S.C. $\S 1973 \mathrm{a}(\mathrm{b})(1994))$.

313. On the vital linkage between the Selma demonstrations of early 1965 and the seminal Voting Rights Act of that year, see GARRow, supra note 92, at 31-178. 


\section{CONCLUSION}

It is interesting to speculate why Smith proved so much more efficacious than either roughly contemporaneous criminal procedure decisions involving the rights of Southern blacks or the slightly later ruling in Brown $v$. Board of Education. While nearly one million Southern blacks registered to vote in the decade after Smith, essentially no blacks served on Southern criminal juries as long as two decades after Norris $v$. Alabama ${ }^{314}$ and fewer than two percent of Southern black school children attended integrated schools a decade after Brown. ${ }^{315}$ A variety of factors may determine the relative efficacy of particular Court decisions.

One reason Smith may have had more dramatic consequences for black voter registration than Brown had for Southern school desegregation is that the black community was more united behind, and more intensely committed to, securing the right to vote than the right to attend integrated schools. Voting is preservative of other rights, ${ }^{316}$ and many black leaders through the 1950s insisted that if Southern blacks were genuinely protected in their right to vote, they could secure other rights for themselves through the political process. ${ }^{317}$ Also, the democratic ideology of World War II more directly implicated the right to vote than the right to nonsegregated education. How could one possibly justify denial of suffrage rights to soldiers who had risked their lives on the battlefield? ${ }^{318}$ Southern black servicemen returning home in the mid-1940s often took their discharge papers straight to city hall so they could register to vote. They did not proceed directly to the local school board, demanding integrated education for their children; legal challenges to public school segregation were still several years in the offing.

Moreover, the black community historically had been far more divided over the pursuit of integrated education than over suffrage rights. ${ }^{319}$ The prospect of genuinely equal, though separate, schools

314. 294 U.S. 587 (1935). On the continued exclusion of blacks from jury service, see Klarman, Criminal Procedure, supra note 6, at 82 (citing various sources); Klarman, Southern Criminal Justice System, supra note 6 (same).

315. ROSEnBERG, supra note 1, at 50; HARVARD SitKofF, THE STRUGGLE FOR Black EQUALITY 1954-1980, at 38 (1981).

316. See, e.g., Harper, 383 U.S. at 667; Reynolds v. Sims, 377 U.S. 533, 562 (1964).

317. For several contemporary statements to this effect, see WILLIAM R. KEECH, THE IMPACT OF Negro Voting: The Role of THE Vote IN THE QUEST FOR EQUALITY 2 (1968); LAWSON, supra note 10, at 128, 147, 166, 238; MoON, supra note 109, at 9. For the argument that Brown might not have been necessary had Southern blacks been fully protected in their suffrage rights, see Michael J. Klarman, The Puzzling Resistance to Political Process Theory, 77 VA. L. REV. 747, 788-819 (1991).

318. For examples of this sentiment, see supra notes 59-60, 120, 124 and accompanying text.

319. For examples of such divisions within the black community, see Davison M. Douglas, The Limits of Law in Accomplishing Racial Change: School Segregation in the Pre- 
held some real appeal to segments of the black community. Separate black schools offered job opportunities for black teachers in an era in which few white collar occupations were open to blacks. They provided an educational environment generally free from the stereotyping, insult, and humiliation that characterized the black school child's experience in that era's integrated schools. Finally, black schools usually presented a more sympathetic portrayal of AfricanAmerican history and culture. None of this is to deny that most African Americans had become enthusiastic integrationists by the postWorld War II period. It is simply to suggest that the black community may have been somewhat more united, as well as intensely committed, on the issue of suffrage rights than on the question of integrated education.

Southern whites, on the other hand, certainly were less intent on resisting black suffrage than integrated education by the late 1940s. Black disfranchisement always had occupied a lower rung on the white supremacist hierarchy of racial preferences than had school segregation. By the 1940s, many moderate white Southerners explicitly endorsed the removal of barriers to black political participation, while remaining adamantly committed to the preservation of public school segregation. ${ }^{320}$ Whites had a harder time justifying black disfranchisement to themselves in light of rising black educational levels and the democratic ideology of World War II. School integration, on the other hand, involved race mixing of young children, male and female, and therefore inevitably entailed for most white Southerners connotations of miscegenation. ${ }^{321}$ Most Southern whites probably also were more resistant to black jury service than to black political participation. Even if blacks became fully enfranchised, whites would retain secure political majorities in most Southern counties and in all Southern states. But criminal juries generally operated on the basis of unanimity, not simple majority rule. Thus, the presence of a single black person on a criminal jury could block the conviction of, say, a

Brown North, 44 UCLA L. REV. 677, 697-701, 712-19 (1997); see also MARK V. TUSHNET, The NAACP's Litigation STRATEGy AGAinst SEGREGATED EDUCATiON 1925-1950, at 8-10 (1987) (describing the debate within the NAACP in the mid-1930s, initiated by a controversial editorial by W.E.B. Du Bois, over whether to condemn public school segregation as well as racial inequality in education).

320. See, e.g., LAWSON, supra note 10, at 148-49, 179-80, 345; see also ARNALL, supra note 116, at 60 (former Georgia governor observing in 1946 that only a "surprisingly small" number of white Georgians favored disfranchisement of literate blacks).

321. See, e.g., Herbert Ravenel Sass, Mixed Schools and Mixed Blood, 198 ATLANTIC MONTHLY 45 (Nov. 1956) ("It is the deep conviction of nearly all white Southerners in the states which have large Negro populations that the mingling or integration of white and Negro children in the South's primary schools would open the gates to miscegenation and widespread racial amalgamation.”); TIME, Dec. 20, 1954, at 54 (reporting Alabama State Senator Walter Givhan observing that the real purpose of the NAACP's school desegregation campaign was "to open the bedroom doors of our white women to Negro men"). 
black man charged with raping a white woman or killing a white man allegedly in self-defense. ${ }^{322}$ Whites concerned about maintaining effective social control over blacks needed to exclude them from juries more than they needed to bar them from politics.

Furthermore, some constitutional rights prove easier to circumvent than others. White Southerners discovered late in the nineteenth century that the most effective means of evading federal constitutional constraints was to delegate unfettered discretion to local administrative officials, who could effectively maintain white supremacy without openly violating the Fourteenth or Fifteenth Amendments. This is how Southern blacks were universally excluded from jury service, disfranchised, and cheated out of their fair share of public school funds. ${ }^{323}$ Over time, however, some of these administrative schemes for perpetuating white supremacy became more difficult to sustain than others. As blacks became better educated, registrars had a more difficult time maintaining with a straight face that black voter applicants had flunked literacy tests that many less welleducated whites had passed. The same was true regarding black representation on jury venires, but the critical difference here was that the peremptory challenge enabled prosecutors to exclude even qualified blacks from serving on petit juries through the 1980s. ${ }^{324}$ There was no analogue to the peremptory challenge in the suffrage context.

In addition, alleged denials of constitutional rights often turn on disputed facts that may prove harder to establish in some contexts than in others. For example, a black Ph.D. from Tuskegee probably would not have had a difficult time demonstrating that he or she was denied the right to register to vote because of race rather than because of failure to pass a literacy test. On the other hand, a black criminal defendant crossing swords with a local sheriff over whether his confession was voluntarily given or induced by a beating would have had a much harder time convincing a (white) fact-finder of the veracity of his account. Thus, the disparate evidentiary burdens inherent in establishing particular constitutional violations may help

322. In other words, continued exclusion of blacks from criminal juries enabled the imposition of racially disparate liability rules. Specifically, only black men received the death penalty for rape (and then only for raping white women), and blacks who killed whites in self-defense generally were unable to mitigate their convictions from murder to manslaughter. See Klarman, Southern Criminal Justice System, supra note 6.

323. See Klarman, Plessy, supra note 15, at 363-65, 374-78, 382-87.

324. Compare Swain v. Alabama, 380 U.S. 202 (1965) (declining to invalidate a prosecutor's use of peremptory challenges to exclude all blacks from a criminal jury in a case involving a black defendant), with Batson v. Kentucky, 476 U.S. 79 (1986) (overruling Swain). As a result of Norris and its progeny, at least a few blacks got onto Southern jury venires by the $1940 \mathrm{~s}$, but it took several more decades before blacks began regularly to serve on petit juries in criminal cases involving allegations of serious black-on-white crime. Klarman, Southern Criminal Justice System, supra note 6. 
explain why Court decisions protecting black suffrage rights proved more efficacious than those forbidding coerced confessions. Relatedly, judges and jurors probably found some rights-bearers more sympathetic litigants than others. Black criminal defendants-indigent, often illiterate and frequently guilty of some crime even if not the one with which they were charged-were less attractive rights-bearers than the middle class, well-educated blacks who endeavored to vote in the postwar years.

The relative availability of sanctions for violations may have been another important factor in determining whether particular constitutional rights were successfully implemented. In the 1940s, law enforcement officers and jury commissioners had little direct incentive to respect the constitutional rights of black criminal defendants because civil or criminal sanctions for violating those rights generally were unavailable. After the Supreme Court's decision in Screws $v$. United States, ${ }^{325}$ courts could impose criminal liability under federal civil rights statutes only in cases involving a crystal clear constitutional violation; official behavior anywhere near the line of permissibility did not qualify as a "willful" violation under the Court's interpretation. ${ }^{326}$ Even in Screws, where the sheriff had wantonly murdered a black prisoner, several Justices balked at applying the federal civil rights statutes. ${ }^{327}$ It is far from clear that a majority of Justices in the 1940s would have been willing to impose federal criminal liability on a law enforcement officer who had beaten a defendant into confessing. Federal lawsuits seeking damages for coerced confessions were equally unpromising. In the 1940 s, it was not clear that state officials acting in violation of state law-and every state forbade coerced confessions - could be sued under the federal civil rights statutes. ${ }^{328}$ Moreover, plaintiffs in such cases-by definition, alleged criminals-were unlikely to arouse great sympathy among jurors.

By way of contrast, Southern voter registrars and party officials were more susceptible to legal sanctions. After Smith, a party official refusing to allow blacks to participate in party primaries had committed a clear constitutional violation that might qualify for federal criminal prosecution, even under Screws' restrictive standard. Civil lawsuits were an even more realistic possibility. The Court's first two white primary cases-Herndon in 1927 and Condon in 1932-had

325. 325 U.S. 91 (1945).

326. Id. at 100

327. Id. at 138 (Roberts, J., dissenting).

328. The Supreme Court did not make it clear that the federal civil rights statutes permitted civil damages actions against public officials who violated state law until Monroe v. Pape, 365 U.S. 167 (1961). On the unanimous rule against coerced confessions, see Report on Lawlessless in Law Enforcement, 10 NAT'L COMM'N ON LAW OBSERVANCE AND ENFORCEMENT 3-4, 25, 28 (1931). 
sustained damages actions under federal civil rights statutes against public officials who refused to allow blacks to participate in Democratic Party primaries. Perhaps one reason that Southern school boards successfully resisted Brown's mandate for so long was that school desegregation litigation in its early phases never sought monetary remedies. ${ }^{329}$

Two final factors that may have influenced the relative efficacy of particular Court decisions in the civil rights context were the quality of the lawyers and the type of courts involved in enforcing the respective rights. Constitutional rights have little value without effective lawyers to raise them, and black criminal defendants almost invariably were impecunious. The court-appointed lawyers they received in capital cases often simply went through the motions of presenting a defense and failed to challenge even clear violations of their clients' constitutional rights. ${ }^{330}$ By way of contrast, blacks challenging denials of their voting rights hired their own lawyers. After World War II, they increasingly found that white lawyers were willing to undertake challenges to black disfranchisement. They also discovered that more, and better qualified, black lawyers were now practicing in the South. ${ }^{331}$

Finally, state appellate and federal judges were more likely than state trial judges to vindicate the constitutional rights of Southern blacks, because they were better educated, more professionalized, and more independent of local public opinion that may have been hostile to those rights. Yet, the cases of black criminal defendants usually did not proceed beyond trial courts, since state provision of counsel for indigents generally did not extend to appeals. Blacks litigating voting rights cases, by way of contrast, were free to choose the forum in which they sued-generally federal court-and they often commanded the resources necessary to pursue their cases to appellate courts, which were more likely to sympathize with their claims. Moreover, the traditional hierarchy of white supremacist values influenced Southern judges as much as anyone else. These judges, as we have seen, were far more likely to sympathize with, and thus to construe liberally, Smith v. Allwright than Brown v. Board of Education. ${ }^{332}$

329. See John C. Jeffries, Jr., The Right-Remedy Gap in Constitutional Law, 109 YaLE L.J. 87, 101 (1999) (speculating that the Justices might have been less inclined to invalidate school segregation in Brown had such a ruling entailed the likelihood of massive monetary liability).

330. For several examples of such sham defenses, see Klarman, Southern Criminal Justice System, supra note 6.

331. See supra notes 151-52 and accompanying text.

332. See supra notes 199-203 \& 208-24 and accompanying text. 
For all of these reasons, Smith proved more efficacious than did contemporaneous criminal procedure decisions involving the rights of Southern blacks or the later ruling in Brown. The lesson seems clear: Supreme Court rulings may have more dramatic consequences in some contexts than in others. While Brown desegregated relatively few Southern schools for a decade, ${ }^{333}$ Smith $v$. Allwright, in conjunction with a propitious set of social and political conditions, set in motion a political revolution in the urban South.

333. Of course I set aside here the question of Brown's more indirect contributions to the civil rights movement. On that point, see the sources cited in supra note 5 . 